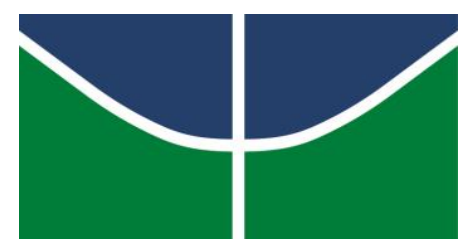

UNIVERSIDADE DE BRASÍLIA - UnB

INSTITUTO DE LETRAS - IL

DEPARTAMENTO DE TEORIA LITERÁRIA E LITERATURAS- TEL

GUILHERME ALVES DA SILVA

MEMÓRIAS PÓSTUMAS DE BRÁS CUBAS COMO FIGURAÇÃO SATÍRICA ESPECÍFICA E A QUESTÃO DA REVOLUÇÃO NO BRASIL 
GUILHERME ALVES DA SILVA

MEMÓRIAS PÓSTUMAS DE BRÁS CUBAS COMO FIGURAÇÃO SATÍRICA ESPECÍFICA E A QUESTÃO DA REVOLUÇÃO NO BRASIL

Trabalho de conclusão de curso apresentado à disciplina Monografia em Literatura como requisito para a obtenção dos títulos de Bacharel e Licenciado em Letras - Português pela Universidade de Brasília - UnB.

Orientadora: Profa. Dra. Ana Laura dos Reis Corrêa. 
GUILHERME ALVES DA SILVA

\title{
MEMÓRIAS PÓSTUMAS DE BRÁS CUBAS COMO FIGURAÇÃO SATÍRICA ESPECÍFICA E A QUESTÃO DA REVOLUÇÃO NO BRASIL
}

\author{
Trabalho de conclusão de curso apresentado à \\ disciplina Monografia em Literatura como \\ requisito para a obtenção dos títulos de \\ Bacharel e Licenciado em Letras - Português \\ pela Universidade de Brasília - UnB. \\ Orientadora: Profa. Dra. Ana Laura dos Reis \\ Corrêa.
}

Data da aprovação:

Profa. Dra. Ana Laura dos Reis Corrêa

Universidade de Brasília 


\section{AGRADECIMENTOS}

À minha orientadora, Ana Laura dos Reis Corrêa, por ter me ensinado para além do conteúdo acadêmico, por ter sido tão acolhedora e prestativa durante toda essa caminhada e por ter me apresentado às ferramentas necessárias para ter contato com uma vida mais rica $\mathrm{e}$ verdadeira por intermédio da literatura.

Aos meus pais por terem me dado uma base familiar tão rica, acolhedora e amorosa. Acredito que sem eles eu não conseguiria chegar aonde cheguei. O esforço que fizeram para que eu pudesse ter o necessário para chegar até aqui está em cada ação que pratico e em cada desejo que realizo.

Aos meus amigos de verdade, Giulliana Diniz, João Pedro, Gabrielle Louise, Lucas Cardosa, Marcos Porto e Laryssa Santana por estarem comigo nesta fase de conclusão de mais um ciclo, mas principalmente por estarem ao meu lado nos momentos mais difíceis de todo esse processo.

À minha professora do Ensino Médio de Literatura, Celina, que me fez ter interesse e fascinação pela leitura (principalmente por Machado de Assis) e fez com que eu desse o

primeiro passo rumo à carreira de professor. À que me inspira até hoje e por quem eu tenho um apresso e admiração imensos. 
"Homo sum: nihil humani a me alienum puto." (Sou homem: não considero alheio a mim nada que é humano)

Publius Terentius Afer 


\section{RESUMO}

Acredita-se que a obra literária Memórias póstumas de Brás Cubas, de Machado de Assis, fornece um reflexo preciso da condição periférica brasileira no século XIX em relação à Europa. Um estudo sobre a relação entre forma estética e conteúdo social no livro permite, assim, com que se chegue a conclusões acerca do uso específico da sátira pelo autor e de que forma este consegue evidenciar de forma efetiva as contradições da época mediante o método compositivo utilizado. A questão da revolução coloca-se como essencial dentro dessa discussão na medida em que ela interfere de maneira direta, como ponto primordial do conteúdo histórico-social nacional, na figuração artística que permeia as Memórias. Por conseguinte, é por intermédio da trajetória de Quincas Borba e de Marcela na narrativa e da educação recebida por Brás Cubas que a dialética entre reflexo artístico e matéria social pode refletir a essência das relações humanas que permearam a independência política do país e seus desdobramentos.

Palavras-chave: Machado de Assis. Sátira. Condição periférica. Revolução. 


\begin{abstract}
It's believed that the literary work Memórias póstumas de Brás Cubas, Machado de Assis, precisely describes the brazilian outskirts condition during 19th century comparing to Europe. A research about esthetic form and social content in the reading allows one to achieve such conclusion about the use of specific satire by the writer and also in what way the author is able to emphasize, effectively, the contradiction of that time, all using the method. The issue of the revolution is highlighted as essential within the discussion, as far as it interferes directly as the primer nacional historical-social topic, within the artist context that permeates the memories. Consequently, it's by Quincas Borba and Marcela's path and Brás Cubas' education, that the dialect between the art and social report may reflect the essence of human relation, which permeated the political independence and its unfoldings.
\end{abstract}

Keywords: Machado de Assis. Satire. Outskirt condition. Revolution. 


\section{SUMÁRIO}

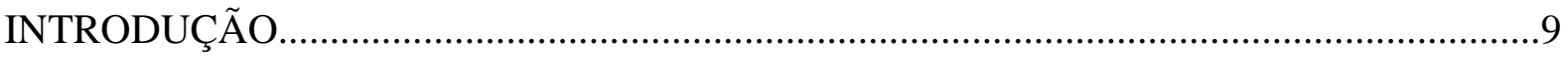

1 CONDIÇÃO ARTÍSTICA NO SÉCULO XIX: REALIDADE EUROPEIA E A

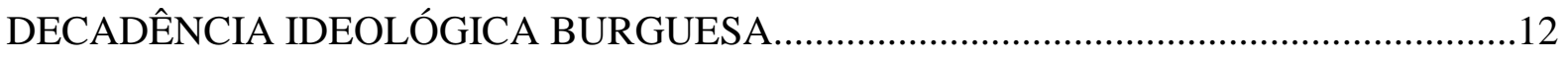

1.1. O método satírico de representação da realidade na Europa.........................................15

2 A PERIFERIA DE MEMÓRIAS PÓSTUMAS: O PROBLEMA DA REVOLUÇÃO..........24

2.1. A figuração satírica machadiana: a estética da revolução em condição periférica........31

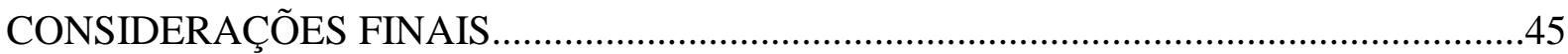

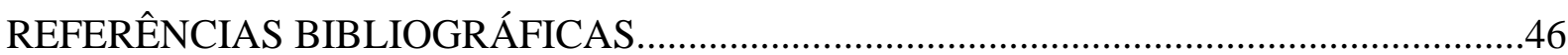




\section{INTRODUÇÃO}

Dentro de Memórias póstumas de Brás Cubas, de Machado de Assis, há, como em qualquer obra de arte verdadeira, uma imbricada relação entre forma e conteúdo, a qual se propõe a nos fornecer um reflexo fidedigno de uma etapa específica do desenvolvimento humano. É na forma naturalmente diversa da construída dentro do realismo balzaquiano que o realismo de Machado de Assis apresenta-se como possível. Apesar de épocas similares, os autores optam por reproduzir reflexos específicos, diversos quanto ao território nacional, tornando cada um dos casos passíveis de concretização, na medida em que se lida com um realismo não baseado em métodos rígidos e imutáveis, mas como configuração que, para se fazer válida, precisa considerar as próprias contradições do tempo e do espaço que se propõem a refletir.

A hipótese desta monografia é a de que as memórias de um integrante da elite senhorial brasileira do século XIX contadas por ele mesmo em situação póstuma refletem as mais profundas contradições que envolviam o país em seu momento crucial de autoafirmação como Nação independente. Sua composição estética satírica e irônica é formada a partir da condição em que se dá tal transposição política, a fim de rebaixar o discurso imperante que tentava encobrir as incompatibilidades ideológicas a partir da manutenção de estruturas sociais e morais ultrapassadas.

Entende-se que investigar as relações possíveis entre a condição estética das Memórias e seu teor social é compreender de que maneira esta age de forma determinante para a formação estruturante daquela. Longe de ser uma questão rápida e simples, deve-se considerar não só o recorte histórico refletido na obra artística; nem se deve limitar aos contornos geográficos colocados; mas sim considerar esse intervalo temporal como parte da história do desenvolvimento humano em suas íntimas e dinâmicas relações. Como coloca Lukács, a forma estética genuína e original

\footnotetext{
é sempre a forma de um determinado conteúdo. Ao afirmarmos isto, não devemos perder de vista de que à estética como ciência cabe descobrir leis o mais possível universais, e cabe à crítica aplicá-las a obras singulares (ou grupo de obras singulares). (...) a forma artística precisamente quando tiver importância estética - é a forma específica e peculiar daquela determinada matéria que constitui o conteúdo de uma dada obra (LUKÁCS, 1978, p. 183184).
}

Assim, para que se entenda a utilização do método satírico por Machado de Assis como forma estética mais eficaz de representação da realidade social de seu tempo e como ele se constitui enquanto reflexo de um conteúdo nacional, deve-se considerar, também, a matéria histórico-social mais abrangente da qual a parte refletida na obra faz parte e mantém relações 
diretas e indiretas. Necessita-se, portanto, admitir a passagem do Brasil de colônia à nação independente, a condição escravagista mantida, suas contradições internas em estreita relação com a condição que se estabelecia na Europa de avanço do capitalismo em seu momento crucial para a história da humanidade: a adesão da burguesia às forças reacionárias em um momento de revolução, ou seja, a vitória da decadência ideológica e seus posteriores efeitos na vida humana concreta. A doutrina do liberalismo chegava ao Brasil e tentava se adequar a uma realidade diversa da qual foi originado.

A relação que Machado estipula dentro das Memórias com autores satíricos do passado retoma uma tradição não como saudosismo idealista nem retomada acrítica das formas antigas de composição, mas como percepção da unicidade da história e concepção madura de mundo. As menções iniciais de Brás Cubas à "forma livre de um Sterne ou de um Xavier de Maistre", as referências à obra satírica de Sêneca e a profunda relação que as Memórias possuem com a tradição luciânica da sátira menipeia corroboram uma visão profunda de Machado de Assis acerca da realidade nacional, ao recuperar momentos históricos em que a sátira foi ferramenta fundamental de denúncia por intermédio da paródia, do riso e do rebaixamento de valores sociais vis e incongruentes.

Mas é no romance satírico do século XVIII de Voltaire que decidimos nos atentar. Cândido, ou o Otimismo traz uma discussão filosófica rodeada de ironia acerca da doutrina otimista, a qual é suscitada pelo personagem machadiano Quincas Borba ao explicitar sua criação ao amigo Brás Cubas: o sistema filosófico do Humanitismo. A intenção é apontar, a partir de Cândido, como Machado compõe esteticamente as Memórias como sátira da condição brasileira oitocentista. A imbricada relação com os autores satíricos que retomam a tradição luciânica da antiguidade clássica encontra, em Memórias póstumas de Brás Cubas, feição particular, na medida em que a forma estética encontra como determinantes conteúdos histórico-sociais diversos.

O problema da sátira como método de composição, a partir dessa discussão, assume em Machado uma dupla complexidade: à medida que a relação entre estética e matéria social se estabelece de maneira dialética para a compreensão exata da necessidade de utilização da composição satírica pelo autor, considerando a condição periférica do país como fator preponderante para a situação brasileira particular do século XIX, o contexto apologético que vive a Europa a partir de 1848 traz consequências estruturantes fundamentais que ressoam de maneira particular em ambiente nacional. Ou seja, o subdesenvolvimento brasileiro é admitido como parte integrante do conteúdo histórico-social nacional, crucial no contato deste 
com a situação europeia de decadência, o que determina, na tentativa de refletir essa realidade objetiva, a composição artística machadiana.

Ponto central do conteúdo refletido na obra é a questão da revolução. Pode-se perceber, na trajetória tanto de Quincas Borba quanto de Marcela, nuances das transformações ocasionadas a partir da independência política do Brasil e da maneira como foi controlada. $\mathrm{O}$ mantimento das estruturas sociais reveladas pela forma artística por intermédio da filosofia humanitista de Borba, assim como sua oscilação entre uma classe e outra mediante herança do tio, suscita questões importantes para se entender como se deu a ideia de revolução na periferia do capitalismo. A condição estrangeira de Marcela e a derrocada que sua vida toma aos fundos de uma relojoaria revela-nos outra face essencial: a comercialização cada vez mais intensa no país como consequência da instauração do pensamento liberalista pósindependência e seu caráter degradante que diferencia ainda mais os integrantes de classes distintas, à medida que rebaixa à miséria e ao descaso os homens livres não detentores de terras.

Admite-se, aqui, a perspectiva de Florestan Fernandes (1975) de que houve uma revolução burguesa no Brasil, só que em seus limites e em suas contradições específicas. Tal força revolucionária, contraditória em si mesmo, foi crucial para que Machado pudesse caracterizar Brás Cubas como representante das camadas mais altas da sociedade e como porta-voz da decadência de sua classe por intermédio da contagem da história de sua vida, única forma de revelação da essência histórica enraizada nos fenômenos superficiais. Suas confissões pós-morte aparecem como artifícios satíricos da desfaçatez que rondava a vida dos senhores aristocratas, que mantiveram a estrutura social colonial como forma de resguardar o prestígio que almejavam.

Dessa forma, é acreditado que o estudo entre a forma artística das Memórias póstumas de Brás Cubas e o conteúdo que ela reflete, a partir da ótica da revolução e como ela é percebida e desenvolvida no Brasil, possibilita-nos uma compreensão mais profunda acerca daquele momento histórico tão importante para o país. A sátira é trazida para essa reflexão como elemento estético primordial que melhor serve para Machado de Assis em seu ofício como escritor, na medida em que transparece a ligação entre a condição periférica brasileira do século XIX e as influências da decadência ideológica burguesa do centro europeu. 


\section{CONDIÇÃO ARTÍSTICA NO SÉCULO XIX: REALIDADE EUROPEIA E A DECADÊNCIA IDEOLÓGICA BURGUESA}

A publicação de Memórias póstumas de Brás Cubas no Brasil em 1881, desenvolvido inicialmente em folhetim em 1880, foi recebida com agitação peculiar por parte da população letrada e por parte da crítica: tentavam entender o que tinha acabado de surgir. Como ruptura evidente da tradição literária brasileira da época, a estranheza receptiva foi aos poucos ganhando ares de aclamação, na medida em que se foi avaliando e se aprofundando nos estudos da obra.

De fato, muitos são os entroncamentos propostos por Machado naquela em que seria sua porta de entrada para sua fase madura: uma narrativa fragmentada, mergulhada na ironia sutil de um defunto, ex-integrante da classe dirigente brasileira, que decide contar sua própria história, surge dialogando com discussões que floresciam na época, ultrapassando os limites territoriais de sua nação.

Com o país independente politicamente desde 1822 e com uma República prestes a estourar, surge uma figura sem papas na língua a fim de contar sua própria trajetória de vida. Enquanto a Europa vivia a ascensão e o declínio de movimentos revolucionários e de ideais democráticos, a condição brasileira permitia que, mesmo depois de morto, um representante da elite teria seu local de fala e seria ouvido. O aproveitamento da situação pelo escritor adveio como oportunidade única de se discutir o atraso do país em relação ao que se revelava do outro lado do oceano, o que também se torna passível de análise nas Memórias.

Não só se torna passível de análise, como tal análise se torna necessária para a compreensão da história do nosso país, já que esse se constitui como território nacional a partir de sua situação como colônia portuguesa. Fato é que Brás Cubas nasce em 1805 e vive a transposição do estatuto colonial para o estatuto nacional durante sua juventude, enquanto se encontra embebecido de amores por Marcela, moça espanhola que encontra em Cajueiros, na ceia de moças, para onde foi levado por seu tio João. Todo o pano de fundo histórico é suprimido na narrativa, com apenas algumas alusões, como a do jantar da família Cubas para comemoração da queda de Napoleão Bonaparte na Rússia. No mais, o foco do lado de cá fíca sendo a impenetrabilidade de uma elite que se interessa pela independência política de seu país com o intuito de ampliar sua atuação de dominância. O plano estético central das Memórias póstumas é o da vida pequeno-burguesa que se mantém estruturalmente inabalada em suas frivolidades e que apaga sua ligação histórica mais profunda com as forças reacionárias que conseguiram manter-se de pé após 1848. 
As Memórias de Machado de Assis têm importância estética, pois se concretizam como realização artística verdadeira em meio a um tempo em que a decadência ideológica dominava praticamente todos os setores da vida social. A produção intelectual, inclusive literária, cede a uma mera reprodução dos fenômenos superficiais como consequência do rumo que a história toma a partir da tomada de posição apologética da burguesia, quando esta renuncia a todos os princípios revolucionários pelos quais vinha lutando ao lado do proletariado desde o início das ondas de revolta contra as monarquias absolutistas europeias em meados do século XVIII.

Marx propõe-se a desenvolver uma crítica em torno dos direcionamentos dados pela atividade intelectual pós-1848, em que ele assume que houve um tratamento mais completo dado à ciência da história, à economia e à filosofia, pois, dentro de suas limitações, consideravam as verdadeiras contradições responsáveis pelo desenvolvimento e pelo progresso da humanidade. Após a derrocada dos ideais democrático-revolucionários pela apologética burguesa, os estudos das vertentes de pensamento humano (economia, filosofia, história, arte) passam a se limitar, gradativamente, à aparência dos fenômenos sociais, impossibilitados de reconhecer o verdadeiro curso da história e sua dialética imanente e tendendo, cada vez mais, à mistificação. Assim:

\begin{abstract}
Essa liquidação de todas as tentativas anteriormente realizadas pelos mais notáveis ideólogos burgueses no sentido de compreender as verdadeiras forças motrizes da sociedade, sem temor das contradições que pudessem ser esclarecidas; essa fuga numa pseudo-história construída a bel prazer, interpretada superficialmente, deformada em sentido subjetivista e místico, é a tendência geral da decadência ideológica. Do mesmo modo como, em face da revolta de junho de 1848 do proletariado parisiense, os partidos liberais e democráticos fugiram e se esconderam sob as asas dos vários Hohenzollern, Bonaparte e consortes, agora fogem também os ideólogos da burguesia, preferindo inventar os mais vulgares e insípidos misticismos a encarar de frente a luta de classes entre burguesia e proletariado, a compreender cientificamente as causas e a essência desta luta (LUKÁCS, 2010B, p. 53-54).
\end{abstract}

Marx desmascara essa tendência da decadência revelando o espírito burguês por trás da retórica formalmente elaborada e artificiosa que assume a posição principal em vez de confrontar, de maneira corajosa, as convicções subjetivas com a realidade concreta. Os desejos individuais de uma classe são colocados como força motriz do progresso humano, o que, junto com a estagnação do reconhecimento das tendências dinâmicas da vida objetiva, ou a própria ignorância delas, fazem surgir a atmosfera do período burguês decadente.

Apesar de as possibilidades de concretização de uma arte autêntica se reduzirem e apesar de a relação mútua necessária entre escritor e realidade se tornar, cada vez mais, difícil 
no período decadentista, continua viva a promessa de realização de uma literatura que visa à superação dos preconceitos equivocados que a burguesia divulga sob as mais variadas formas a respeito do homem e do mundo. Quando tal superação é alcançada, atinge-se, assim, o "Triunfo do Realismo", quando a possibilidade de um reflexo exato e profundo da realidade é concretizado como resultado pela sinceridade subjetiva do autor em contato com o conteúdo social e ideológico determinante. Para que isso ocorra, o escritor precisa se desprender de uma série de preconceitos que permeiam e dificultam o seu acesso a uma visão mais profunda da realidade a qual pretende figurar; precisa

ter uma concepção do mundo sólida e profunda; precisa ver o mundo em seu caráter
contraditório para ser capaz de selecionar como protagonista um ser humano em cujo
destino se cruzem os contrários. As concepções do mundo próprias dos grandes escritores
são variadíssimas e ainda mais variados são os modos pelos quais eles se manifestam no
plano da composição épica. Na verdade, quanto mais uma concepção do mundo é profunda,
diferenciada, alimentada por experiências concretas, tanto mais variada e multifacetada
pode se tornar sua expressão compositiva (LUKÁCS, 2010B, p. 179).

À medida que se tornam válidas diversas concepções de mundo - profundas em suas experiências concretas - e materializadas múltiplas expressões compositivas, o "Triunfo do Realismo" pode surgir em contextos vastos, de nações altamente desenvolvidas economicamente até países em condições periféricas subdesenvolvidas. A personalidade estética subjetiva do autor, em contato com as forças motrizes do processo social em um determinado momento histórico, que condiciona ambiente necessário para a realização artística completa capaz de refletir coerentemente a vida.

A construção de um mundo inteiriço em que o mundo interno das personagens entra em constante relação com o mundo externo, assim como na vida concreta, disputa e perde espaço a partir do final da primeira metade do século XIX. A ação, central para o desenvolvimento da obra, cede lugar a descrições isoladas de coisas, paisagens, quadros inertes e estudos magistrais que reduzem a vida a fragmentos desconectados, entediantes e repetitivos. Esse descritivismo que sai de seu lugar periférico nas narrativas do século XVIII a favor da narração para ocupar posição central a partir de meados do século XIX é reflexo do progresso capitalista que produz incessantemente a mecanização da vida. A literatura burguesa moderna passa a produzir de forma fragmentada a realidade defendendo um posicionamento falso da impossibilidade de compreensão da realidade, transformando a vida em natureza morta, em sucessões do mesmo quadro. Logo, não traz nada de novo nem de essencial, já que fica presa à superfície dos fenômenos imediatos.

A transformação da descrição em método dominante da composição épica é um fenômeno que ocorre em um período em que se perde, por motivos sociais, a sensibilidade para os momentos essenciais da estrutura épica. A descrição é um sucedâneo literário destinado a encobrir a carência de significação épica (LUKÁCS, 2010B, p. 165). 
Em relação ao impacto desse momento historicamente decisivo em regiões periféricas como o Brasil, a decadência assume caráter particular, sendo, por isso, igualmente diversa a forma como seu contato com condições concretas particulares é refletido pela arte. Machado, em Memórias póstumas de Brás Cubas, capta aquele ponto onde o chão histórico específico entra em contato com a perspectiva burguesa caduca de progresso. Do lado de cá do oceano, a desfaçatez da classe elitista será encarnada pela personagem principal como forma encontrada de mascarar a incompatibilidade entre a manutenção das estruturas coloniais e a adoção de uma ideologia liberalista burguesa, ponto central satirizado na obra machadiana. A sátira, assim, constrói-se de forma diversa da sátira europeia, mas constitui-se tendo em vista o mesmo objetivo: combater os vícios essenciais de uma sociedade problemática e corrupta. Percebe-se, com as Memórias, que "por trás da pomposa fachada de frases grandiosas de profunda ressonância, inclusive "revolucionária", revela-se sempre de novo (...) a viscosidade, ao mesmo tempo covarde e brutal, do pequeno-burguês capitalista” (LUKÁCS, 2010B, p. 60), que, em situação periférica escravagista, assume contradições particulares.

\subsection{O método satírico de representação da realidade na Europa}

Como disse Marx, a produção intelectual no período anterior ao período da decadência ideológica, apesar de enfrentar limites, como em qualquer etapa do desenvolvimento da humanidade, encarava suas próprias contradições tentando entender a relação dialética entre fenômeno e essência, de maneira total e dinâmica. A construção do reflexo satírico da realidade, assim, estabelece-se dentro da estética nesse momento pré-decadência burguesa de maneira diversa da forma que será elaborada posteriormente. Não cabe aqui, entretanto, o mero contraste da qualidade de construção formal das obras satíricas pós e pré-período apologético da burguesia, que teve início em 1848. Notório é, todavia, que a possibilidade de realização do "Triunfo do Realismo" se torna menor graças às forças retrogradas que agem

durante essa época, mas não a impedem de se concretizar, a partir de um esforço consequentemente maior por parte do escritor para compreender as forças motrizes do processo social que se encontram mais deturpadas e fragmentadas que antes.

A partir disso, Cândido, ou o Otimismo, de Voltaire, é resgatado dentro do mundo criado em Memórias póstumas, pelo filósofo Quincas Borba, como retomada histórica de um período anterior à derrocada das revoluções europeias. Ao expor seu novo modo de ver o mundo, a filosofia do Humanitismo, as semelhanças com as concepções de Pangloss 
aparecem. O Humanitismo surge no livro como filosofia criada por Quincas, amigo de infância do personagem principal, Brás Cubas. Após furtar com um abraço o relógio do amigo em um momento de extrema necessidade, envia-lhe uma carta restituindo o objeto furtado, por ter recebido a herança de um tio. Nessa carta, expõe também seu objeto criador, "fruto de longo estudo", seu novo sistema filosófico, "destinado a arruinar todos os demais sistemas", no qual vai delineando uma teoria acerca do homem revestida de todo ar empoderado que tem um filósofo. É criada uma visão do mundo, lugar onde "não há aventuras fáceis, nem quedas, nem tristezas, nem alegrias pueris" e onde, “verdadeiramente, há só uma desgraça: é não nascer"1.

Sendo assim, Quincas Borba revela a lógica do Humanitismo, baseada a priori na vontade humana de viver e de se manter vivo. De início, o autor do novo modo de se pensar a humanidade baseia seu trabalho em exemplos prosaicos, justificando a vida na realização de atividades cotidianas, como conversar com o amigo de infância após longo período, comer uma batata, ir ao teatro, "para tudo, dizer uma só palavra: viver", coloca Joaquim Borba dos Santos. Como consequência disso, todos os acontecimentos que são tidos normalmente como perturbadores da ordem e da paz, como a guerra, a insurreição, a miséria, a doença e a fome, tornam-se plenamente justificáveis dentro da filosofia de Borba, logo que, ou fazem parte de um processo como operações convenientes, ou são, como diz o próprio criador, "verdadeiros equívocos do entendimento, porque não passariam de movimentos externos da substância interior (...) como simples quebra da monotonia universal (...) [o que] não impediria a felicidade humana" (ASSIS, 2011, p. 221).

Com a extinção da dor, Quincas Borba acredita que a vida é o bem mais precioso que existe, "e não há mendigo que não prefira a miséria à morte (o que é um delicioso influxo de Humanitas)". Todos os fatos são entendíveis e explicáveis dentro de sua nova filosofia, pois a vida humana se mantém independentemente dos desvios de percurso, o que é sublime. Assim, como consequência, também toda crueldade e sofrimento presentes no cotidiano desaparecem, ou não possuem importância dentro do sistema, tornando-se meros empecilhos, detalhes de pouca relevância, uma revitalização maquiavélica de que "os fins justificam os meios", autor utilizado de forma rebaixada, aliás, como instrumento para engrandecer o discurso paterno na "Teoria do medalhão", quando comparado com $O$ Príncipe, obra de extrema importância histórica, artifício tão bem apossado por Borba. Aos poucos, o egoísmo vai se delineando por trás das exposições e exemplos que o filósofo utiliza, escondido, na

\footnotetext{
${ }^{1}$ ASSIS, 2008, p. 219.
} 
maioria das vezes, pelas citações e comparações com grandes autores do passado, sempre os diminuindo e exaltando sua capacidade e seu grande objeto de estudo. Antonio Candido (2004) lança luz a esse tema na obra de Machado referindo-se a ele como "um dos demônios familiares", a exploração do homem pelo homem, condição ligada à falta de liberdade verdadeira. É no exemplo de Quincas Borba sobre a origem e o percurso do frango até sua mesa na companhia de Brás Cubas que o verdadeiro eixo condutor de sua filosofia começa a se descortinar:

Mas eu não quero outro documento de sublimidade do meu sistema, senão este meu frango. Nutriu-se de milho, que foi plantado por um africano, suponhamos, importado da Angola. Nasceu esse africano, cresceu, foi vendido; um navio o trouxe, um navio construído de madeira cortada no mato por dez ou doze homens, levado por velas, que oito ou dez homens teceram, sem contar a cordoalha e outras partes do aparelho náutico. Assim, este frango, que eu almocei agora mesmo, é resultado de uma multidão de esforços e lutas, executados com o único fim de dar mate ao meu apetite (ASSIS, 2008, p. 220).

A justificativa dada para a "multidão de esforços e lutas" que fizeram com que Quincas estivesse comendo o frango naquele momento é completamente autossuficiente na situação literária, tanto para o emissor quanto para o receptor. Segundo Daniel Fonseca (2014), em sua análise acerca da ironia em Dom Casmurro, "Os escravos aparecem em ligação direta com o capital, como parte dele; são figuradas ainda sua condição de instrumento ou mercadoria e a naturalização dessa condição pelos proprietários” (p. 48). Para o autor, só a partir da escravidão que é possível entender o grau de subordinação que padecem homens e mulheres livres e pobres, o que se figura nas Memórias no caso do negro Prudêncio e da D. Plácida. No caso de um, que era feito de cavalo quando criança, há a permanência da fidelidade ao senhor como única forma de sobrevivência, ao passo que no da outra, sua subordinação é elevada à condição de álibi da traição de Virgília e Brás Cubas, mas que só veio

para queimar os dedos nos tachos, os olhos na costura, comer mal, ou não comer, andar de um lado para o outro, na faina, adoecendo e sarando, com o fim de tornar a adoecer e sarar outra vez, triste agora, logo desesperada, amanhã resignada, mas sempre com as mãos no tacho e os olhos na costura, até acabar um dia na lama ou no hospital (ASSIS, 2008, p. 167).

Para, mais uma vez, realçar a superioridade do Humanitismo, o filósofo invoca a figura de Pangloss, oráculo da família de Cândido, da obra de Voltaire, afirmando que o primeiro não era tão tolo como o pintou o último. Ao reacender a proposta filosófica otimista de que o mundo seria o melhor dos mundos possíveis, ridiculariza a relevância da obra de Voltaire ao esvaziar a importância à condenação suscitada pelo livro das práticas desumanas do tempo. Nesse momento, ficção e realidade se misturam para anular uma proposta de um escritor real em situação real, a favor do devaneio de um louco. 
Por conseguinte, pode-se dizer que Memórias consegue figurar aquele momento da vida cotidiana periférica brasileira que se coloca por si só como sátira pronta e acabada. Em relação ao contexto brasileiro, a desfaçatez de classe traz à superfície sensível a essência do seu determinado estágio de desenvolvimento social, apresentando-se na própria realidade como um caso particular em que encarna a unidade imediata e o contraste imediato entre essência e fenômeno. A forma satírica das Memórias póstumas brota como força espontânea em estágio desenvolvido de embriões e elevado à forma, presente na própria vida, figurando como necessário o que surgiu apenas "por acaso" na realidade.

Enquanto em outras formas de figuração, representando todos os elos intermediários, revela-se a complexa dialética do acaso e da necessidade, superando assim o acaso. Na sátira é como acaso que o acaso deve elevar-se à necessidade. Sua necessidade reside no fato que a simples possibilidade do acaso expressa a essência do sistema em cujo seio ele foi produzido; quando a simples possibilidade do objeto de representação satírica é suficiente para o desmascaramento do sistema figurado e para a revelação de sua essência real, a sátira pode ser efetivamente elevada à forma.

No caso artístico machadiano, os desejos supérfluos e pueris de Brás Cubas que moveram toda sua vida são capazes de revelar a contradição mais íntima de sua própria classe, a obtenção do poder não só social, mas também político e econômico às custas das mazelas já exploradas. O que é evidentemente contraditório na vida passa a ser admitido como harmonioso nas Memórias, o que gera o contraste, pois o típico, na sátira, "é assim alcançado por meio da abolição da forma contraditória no seio do conteúdo adequado de sua própria contradição" (LUKÁCS, 2011, p. 177). As contradições da forma, assim, colocam-se como um reflexo das contradições da dialética do conteúdo, "mas este reflexo não se dá diretamente, por meio da simples figuração das contradições, mas de tal modo que a criação da forma reproduza, em sua estrutura, a contradição fundamental do conteúdo" (ibidem, p. 177).

Se focarmos novamente na particularidade brasileira, toda justificativa da escravidão se torna possível, em um primeiro momento, como Roberto Schwarz (1981) expõe brevemente em Complexo, moderno, nacional e negativo, porque a classe dirigente brasileira do século XIX ainda tinha sua base econômica escravocrata, não podendo abrir mão dela para se chegar aos fins desejados, à obtenção de riquezas por meio da exploração da mão de obra trazida principalmente da África. Por conseguinte, a necessidade nacional de se afirmar integrante da ordem mundial e de seus princípios fundamentais vinha sempre acompanhada da negação destes princípios quando os olhos se voltavam para dentro. A profunda 
contradição da camada política representante do país advinha de sua dependência e constante manutenção do sistema escravista, ao passo que queria obter um lugar de renome no cenário prioritariamente europeu, o qual não condizia imediatamente com seus métodos periféricos de comando do país.

Emerge, assim, a trágica situação do africano "suponhamos, importado da Angola" que fez com que a comida estivesse na mesa naquele momento, tragédia ignorada filosoficamente pela necessidade final de acabar com a fome de um recém-tornado integrante da classe detentora do poder econômico por meio da herança de seu tio de Barbacena. Percebe-se, contudo, que a filosofia que vai "desde as formas mais atenuadas do simples egoísmo até os extremos do sadismo e da pilhagem monetária" (CANDIDO, 2004, p. 28) é resultado da realidade concreta e se coloca como fenômeno fetichizado, e não como parte constituinte da essência humana. A reificação das relações humanas deixa o egoísmo efetivarse, criando a falsa impressão mística de que este é intrínseco ao homem.

A redução das individualidades humanas à soberba é mais evidentemente percebida quando Quincas Borba expõe a Brás Cubas a sua teoria do benefício. A insistência da memória do benefício que se manteria mais no beneficiador do que no beneficiado, segundo o filósofo, "explica-se pela natureza mesma do benefício e seus efeitos", ou seja, o sentimento de boa ação é utilizado apenas como intermédio entre a ação e a afirmação da própria superioridade do beneficiador. O raciocínio é distorcido e posto ao avesso, sempre tratado com a maior normalidade, sem a possibilidade de contestação. A comparação com os burros que se coçam, referência à obra de Erasmo, humanista holandês, acaba sendo mais perversa: apesar de o homem se diferenciar do animal por "ter consciência", as comparações entre os dois seres que são feitas pelo filósofo ao decorrer de sua passagem no livro aproximam-nos, mais para bestializar o comportamento de um do que humanizar o do outro. Assim, a única diferença entre um cão que briga com um homem por comida é a consciência do último de que "sabe que tem fome", paródia de Pascal elevada pelo tom filosófico à observação metafísica. Fenômeno espetacular no Humanitismo, ao transpor-se para o espaço extranarrativo, expõe a ignorância da miséria e desigualdade econômica por parte da elite brasileira escravocrata.

Nas Memórias, portanto, o sentimento de completude argumentativa do autoproclamado filósofo se esvaece ao sair da situação ficcional e atingir o leitor: é o lado real, o verdadeiro apoio da ação e da lógica do romance, que nos dá a impressão de "fantasia risível”, como revela Schwarz (1981). E é ele próprio que explica a impressão destoante causada no leitor, já que "o critério da realidade que preside à caracterização é um, e o que 
comanda a ação é outro, sendo que num caso a norma é juiz, e no outro, como vimos, objeto de capricho" (SCHWARZ, 1981, p. 49). Sendo assim, o enredo frouxo de Memórias póstumas, conduzido e elaborado pela volubilidade do narrador, o que, em uma perspectiva interna, é tido como realidade última confessada apenas em morte, apresenta-se envolvido pelo método de composição machadiana que eleva as necessidades das personagens ao âmbito do capricho, como o desejo de notoriedade por intermédio do emplasto Brás Cubas. O que para o narrador, assim como para as demais personagens, é essencial para a vida, como o desejo de Cubas de se tornar ministro e até de se casar, pois "todo homem público deve ser casado", evidencia-se como frivolidade fora do critério de realidade que abarca o romance, ou seja, no campo real objetivo que Machado revela para além da realidade imediata das Memórias, o qual se reflete de forma mais profunda como método que interliga a aparência da realidade cotidiana à essência encoberta pelos panos desta em uma relação contraditória que enriquece a obra.

Voltaire acaba desenvolvendo, no século XVIII, de forma diversa, uma sátira que $a$ priori possui o mesmo objetivo: fazer transparecer os vícios mais evidentes de uma classe ou sociedade como um todo de modo a se elevar à condição artística da sátira. Cândido ou o Otimismo, em 1759 - data de publicação - traz uma doutrina que se vai tornando cada vez menos crível quanto mais entra em choque com a concretude dos fatos reais. A falsa impressão “otimista” pregada pelo oráculo Pangloss se desfaz em um mar de decepções e sofrimentos; o desespero é efeito imediato da revelação causada pelo tom satírico do livro.

Cândido habita um mundo repleto de desastres, guerras, catástrofes, cheio de práticas desumanas, e, apesar de sempre tentar implantar os ensinamentos do oráculo Pangloss, desespera-se. No Suriname, vê um escravo sem um braço por causa de um acidente no engenho de açúcar, e sem uma perna por ter tentado fugir. O desvendamento das reais práticas que possibilitam a comercialização do produto é revelado pela boca do próprio escravo, "é a esse preço que vós comeis açúcar na Europa" (VOLTAIRE, 2012, p. 83), o que remete à lembrança de Brás Cubas sobre a explicação retórica de Quincas Borda acerca das origens do frango que comia com seu amigo. Enquanto no primeiro é possível dar voz ao escravo, no segundo, as condições histórico-sociais impossibilitavam o ato direto de revelação, sendo apenas possível pela rememoração de um morto dentro da filosofia de um louco.

Com isso, em Cândido, há a ridicularização da doutrina de que tudo está ótimo no melhor dos mundos possíveis, um Otimismo na forma de uma vasta e mordaz farsa dele. Entretanto, este posicionamento de que tudo está bem não é maluquice provinciana, mas se respalda na crença de que tudo é controlado por leis imutáveis, o único mundo possível, 
eliminando outras opções. O idealismo filosófico da época é englobado pela crítica satírica do autor e se relaciona com o interesse de classe de uma burguesia que renuncia o meio revolucionário dentro da perspectiva da sátira no que tange a incapacidade de refletir fielmente a essência dos fenômenos sociais. No idealismo, a oposição social concreta na sátira, a crítica de uma sociedade de classe por uma classe que é por ela oprimida, ou a autocrítica de uma classe, é transfigurada numa revolta ética abstrata do indivíduo contra sua época "degenerada".

O Otimismo como corrente filosófica passa a simbolizar uma posição de classe: o mundo está bem para quem? Um imenso caminho sangrento e catastrófico a se seguir pela maioria adquire status de necessidade para que a posição privilegiada de poucos se mantenha. O filósofo defensor do Otimismo no século XVIII, Gottfried Wilhelm Leibniz, que dizia que "as sombras realçam as cores", citado por Voltaire na fala de Pangloss a Cândido, quando diz que os males do mundo são sombras numa bela pintura, revela os limites enfrentados nesse período da história. Até o próprio Voltaire era de acordo com essa perspectiva, todavia deixou-a não por acreditar em sua falsidade, mas por ter a percepção de sua crueldade e chegar à conclusão de que não era possível compactuar com o inaceitável. Tanto o idealismo filosófico quanto seu materialismo podem ser vistos como parte de uma dialética interna enfrentada pelo autor de Cândido. O Otimismo coloca-se como resposta mecânica, fácil demais, que não considera a dialética da vida, pobre de reflexões profundas, generalização vazia e idealista de que tudo vai bem a toda parte porque me encontro ótimo no pedacinho de espaço que ora me encontro.

As conclusões chegadas pela filosofia são desmascaradas por Voltaire parodicamente: o pensamento filosófico de que "tudo que é está certo" toma sua concepção inversa no mundo de Westfália, em que Pangloss é o maior filósofo da região, consequentemente, de toda a terra. Gosta-se das coisas tão como estão na medida em que estas convêm a alguém que não tem conhecimento do que está fora de seu alcance. Tal pensamento filosófico é ironizado em Cândido a partir do limitado campo de visão que generaliza a situação em Westfália para o restante do mundo.

A filosofia coloca-se como acreditável nos momentos de esperança, como efeito da posição privilegiada dos personagens, como quando Cândido, após sua refeição, se lembra dos diamantes no bolso da Srta. Cunegunda. Tudo estar bem se simplifica à mera condição egoísta individual que é satirizada, a todo momento, por Voltaire. Mas, ao mesmo tempo em que é rebaixada em Cândido, tal condição paradoxal em que o personagem principal é colocado evidencia sua necessidade de ser satirizada: a sátira é tida como mecanismo capaz 
de trazer às claras o complexo jogo de forças históricas que atingem a vida humana. Cândido vê-se, em diversos momentos da narrativa, entre a sua inclinação clara ao sistema filosófico de Pangloss e as desgraças com as quais entra em contato durante toda sua trajetória, o que não implica esclarecimento fácil e total. Sua incapacidade em ficar infeliz por muito tempo revela as tendências históricas de sua época, tão quanto o choque estipulado, em certa medida, pela sátira, entre o velho que persiste e a necessidade do historicamente novo.

O final feliz irônico, que traz mais um mal-estar do que uma sensação de conforto, deixa em aberto um embate que se prolonga para além da narrativa. A fala final de Cândido, após concordar com Pangloss acerca da necessidade de todos os infortúnios passados por eles para que pudessem estar comendo com os outros naquele momento, busca revelar a permanência de todo um estado de coisas a partir da manutenção do pensamento classista de egoísmo e passividade diante da dor alheia. “(...) mas é preciso cultivar o nosso jardim”, a fala de Cândido que desfecha o livro, é como decidir não procurar respostas a perguntas que não lhe cabe, manter-se preso e cômodo à sua posição, quando esta lhe é favorável. Uma terapia do esquecimento, uma forma de harmonizar a sorte que lhe é própria à dor alheia.

Por outro lado, considerando o jardim como o mundo da arte, da escrita, cultivá-lo não é um trabalho de alheamento e esquecimento, mas, sim, de lembrança ativa de como é o mundo, ao mesmo tempo em que nos convida a indagar quais partes dele podem mudar. As sátiras (no seu efeito mais direto) não corrigem ninguém, mas é possível achar, em sua mescla de evidência do horror, por meio do rebaixamento irônico do riso, o trabalho a se fazer, ou seja, as direções que apontam para o progresso humano. Esse é a essência do jardim proposto em Cândido, quando aprofundado em suas razões históricas em contato com os fenômenos aparentes que falseiam a imagem do jardim e o transformam em resignação e aceitação da filosofia otimista.

Falar de sátira e compreender sua importância e construção a partir dessa nova etapa é, portanto, crucial a partir da ótica que enxerga a sátira como composição formal crítica de combate abertamente explícito contra os efeitos desumanizadores do capitalismo que começavam a se evidenciar cada vez mais. A partir disso, o problema da sátira consegue trazer à margem os limites da estética burguesa de modo mais nítido e brutal que as demais questões literárias, porque, em sua forma, a relação com o conteúdo de classe se expressa mais imediatamente do que na maioria dos problemas formais da literatura. Isso se deve à sua base: a oposição imediata entre essência e fenômeno. Segundo Lukács (2011), no romance, essa dialética se impõe por meio de um sistema dinâmico de mediações, aparecendo para nós a totalidade social, a imagem universal de uma época ou de um estágio social que o romance 
tem como papel figurar; ao contrário, a sátira constantemente afasta estas mediações. Este afastamento é o fundamento do seu método criador.

Nota-se também que, tendo em vista essa discussão, além de a sátira ser composta de modo mais específico que outras composições literárias, é necessário ter em vista a singularidade da construção formal de cada obra literária, visualizando, nas Memórias póstumas de Brás Cubas, como se dá essa construção e o que a envolve. Por conseguinte,

devemos estudar a forma estética em seu modo genuíno e original de manifestação, tal como a podemos encontrar sobretudo na obra de arte, como objetivação do reflexo estético da realidade, no processo criador e no comportamento estético-receptivo em face da arte (LUKÁCS, 1978, p. 184). 


\section{A PERIFERIA DE MEMÓRIAS PÓSTUMAS: O PROBLEMA DA REVOLUÇÃO}

É no foco que dá na vida de um integrante de classe média alta e em suas relações frívolas com os que o rodeiam que Machado reflete a formação do Brasil como Estado nacional. Como único meio de propagação das ideias, o representante dos estamentos senhoriais que viriam a desenvolver uma revolução para perder o estatuto colonial desenvolve sua autobiografia, em que impera o discurso pomposo e armado como maneira de encobrir o sentido vazio dado a sua vida. Como resultado contrário, a superficialidade é evidenciada por uma força satírica que se coloca acima do controle narrativo tido por Brás Cubas, resultado estético da incompatibilidade ideológica e das ações concretas da classe dirigente nacional chegada recentemente ao comando do país.

Desde o início, é válido sempre sublinhar que a concepção de revolução desenvolvida aqui no Brasil, na passagem do estatuto colonial para o nacional, e estudada por Florestan Fernandes (1975) não se coloca - nem poderia se colocar - nas mesmas condições existentes na Europa a partir da Revolução Francesa no final do século XVIII. Divergentemente, portanto, da concepção de Lenin sobre revolução e greve dos operários, a qual retrata a "necessidade de tornar consciente e de generalizar, fornecendo-lhes bases ideológicas, a insatisfação e a exasperação dos operários que se manifestam espontaneamente nas greves" (LUKÁCS, 2010B, p. 86), a revolução burguesa no Brasil ocorreu dentro dos moldes nacionais e de acordo com uma classe que, para concretizar seus anseios e necessidades particulares, teve que manter a estrutura social, econômica e moral da estrutura colonial.

É na ação dos integrantes que participam da vida de Brás Cubas que a questão da revolução no Brasil pode ser compreendida. Tanto sua origem familiar como sua relação com Lobo Neves e a família do Dutra propõem uma convivência marcada pelo interesse e pelo desejo de, cada vez mais, ascender socialmente, tendo em vista o prestígio social e a fama desmedida. O desvendamento artístico das estratégias utilizadas para encobrir as reais forças que guiavam suas atitudes liga-se à "revolução encapuçada" no Brasil. Segundo Florestan Fernandes,

as elites nativas não se erguiam contra a estrutura da sociedade colonial. Mas, contra as implicações econômicas, sociais e políticas do estatuto colonial, pois este neutralizava sua capacidade de dominação em todos os níveis da ordem social. Por conseguinte, a natureza e o alcance revolucionários da independência não se objetivaram (nem poderiam se objetivar!) através de manifestações de grandes massas humanas, do uso organizado da violência e de anseios coletivos irredutíveis de transformação da estrutura social. Eles se objetivaram na obstinação e na eficácia com que aquelas elites se empenharam na consecução de dois fins políticos interdependentes: a internalização definitiva dos centros de poder e a nativização dos círculos sociais que podiam controlar esses centros de poder. Assim, sem negar a ordem social imperante na sociedade colonial e reforçando-a, ao contrário, as referidas elites atuaram revolucionariamente ao nível das estruturas do poder 
político, que foram consciente e deliberadamente adaptadas às condições internas de integração e de funcionamento daquela ordem social (FERNANDES, 1975, p. 32).

A independência, assim, possui seu elemento revolucionário - de adequação à ordem social colonial à sociedade nacional - e seu elemento conservador - a preservação e fortalecimento da ordem social que não tinha condições materiais e morais suficientes para atingir o grau de autonomia necessário à construção e ao florescimento de uma Nação. Essa coexistência de elementos antagônicos provindos da realidade advinha, por um lado, da superação do estatuto colonial como estado jurídico-político, mas por outro da perpetuação do substrato material, social e moral, que serviu como base para a construção de uma sociedade nacional.

A grande lavoura e a mineração impunham a perpetuação das estruturas do mundo colonial - da escravidão à extrema concentração de renda e ao monopólio do poder por reduzidas elites, com a marginalização permanente da enorme massa de homens livres que não conseguia classificar-se na sociedade civil. A independência foi escondida como processo revolucionário, "graças ao predomínio de influências histórico-sociais que confinavam a profundidade da ruptura com o passado" (FERNANDES, 1975, p. 33).

Quando se olha para a trajetória de Quincas Borba e para seu espaço reservado dentro da autobiografia de Cubas, uma desestabilização na perspectiva naturalista do protagonista evidencia-se. O contraste entre o relato da infância com seu amigo e seu encontro posterior, apenas quando maduros, é gritante e recebido pelo narrador com espanto. Não menos surpreendente é o posterior retorno de Quincas à classe econômica de prestígio, mediante a herança de seu tio, e as posteriores implicações psicológicas na personagem, tanto no que tange à questão da loucura quanto na aceitabilidade do fruto de seu trabalho pelo amigo recém-encontrado, a filosofia do Humanitismo.

Todavia, o que interessa, aqui, é perceber como o contraste entre o status social de Quincas na infância e o na fase madura impacta e interfere na visão de mundo de Brás Cubas. A descrição do amigo no início da narrativa inicia essa reflexão:

Uma flor, o Quincas Borba. Nunca em minha infância, nunca em toda a minha vida, achei um menino mais gracioso, inventivo e travesso. Era a flor, e não já da escola, senão de toda a cidade. A mãe, a viúva, com alguma coisa de seu, adorava o filho e trazia-o amimado, asseado, enfeitado, com um vistoso pajem atrás, um pajem que nos deixava gazear a escola, ir caçar ninhos de pássaros, ou perseguir lagartixas nos morros do Livramento e da Conceição, ou simplesmente arruar, à toa, como dois peraltas sem emprego. E de imperador! Era um gosto ver o Quincas Borba fazer de imperador nas festas do Espírito Santo. De resto, nos nossos jogos pueris, ele escolhia sempre um papel de rei, ministro, general, uma supremacia, certa magnificência nas atitudes, nos meneios. Quem diria que... Suspendamos a pena; não adiantemos os sucessos (ASSIS, 2008, p. 72). 
Ao aproximarmos os sucessos, o leitor é capaz de chegar a conclusões que extrapolam o curso intranarrativo. Após sair da casa do Lobo Neves, Brás Cubas sai andando até encontrar, na rua dos Barbonos, uma sege, onde se encontrava um companheiro de colégio, ministro. A reflexão gerada no protagonista transparece seus desejos: “- Por que não serei eu ministro?". O fato de Brás Cubas conseguir visualizar a si mesmo como ministro - apenas pela possibilidade de um colega escolar ter alcançado tal status - transparece não só a ganância da classe senhoril, da qual Cubas faz parte, mas a lógica decadentista superficial da classe opressora que resume as circunstâncias históricas e dialéticas a relações mecânicas de causa e efeito.

É posteriormente a essa reflexão que ele encontra seu amigo Quincas Borba em situação socialmente oposta à relatada pelo narrador em sua infância:

Imaginem um homem de trinta e oito a quarenta anos, alto, magro e pálido. As roupas,
salvo o feitio, pareiam ter escapado ao cativeiro de Babilônia; o chapéu era contemporâneo
do de Gessler. Imaginem agora uma sobrecasaca, mais larga do que pediam as carnes - ou,
literalmente, os ossos da pessoa; a cor preta ia cedendo o passo a um amarelo sem brilho; o
pelo desaparecia aos poucos; dos oito primitivos botões restavam três. As calças, de brim
pardo, tinham duas fortes joelheiras, enquanto as bainhas eram roídas pelo tacão de um
botim sem misericórdia nem graxa. Ao pescoço, flutuavam as pontas de uma gravata de
duas cores, ambas desmaiadas, apertando um colarinho de oito dias. Creio que trazia
também colete, um colete de seca escura, roto a espaços, e desabotoado (ASSIS, 2008, p.
143).

A concepção naturalista é botada em cheque pelo próprio suceder dos acontecimentos narrados, ao indagar-se o motivo da não realização do mesmo fato a destinos humanos diferentes e ao chocar-se com o declínio econômico de um companheiro de classe. A situação degradante na qual Brás Cubas encontra seu amigo de infância o gera pavor, talvez mais pela visão limitada de mundo do que pelo próprio fenômeno presenciado. "Não; impossível; não pode ser. Não podia acabar de crer que essa figura esquálida, essa barba pintada de branco, esse maltrapilho avelhentado, que toda essa ruína fosse Quincas Borba. Mas era" 2.

"Uma vida de misérias" é tudo que não se espera viver um integrante da elite. Porém, Borba parece vivê-la com "com certa graça indolente", "resignado aos golpes da fortuna". Entretanto, ele experimenta a vida de ambas as classes sociais antagônicas: do pajem que lhe deixa fazer o que quiser, vai morar no terceiro degrau das escadas de São Francisco, situação mais degradante que o faz compreender que os atos extremos são necessários, como furtar o relógio de seu amigo com um abraço.

Daniel Fonseca (2014) chama atenção para a visão naturalista de Bento Santiago em Dom Casmurro, o que não significa a aderência de tal perspectiva pelo autor original do livro,

\footnotetext{
${ }^{2}$ Ibidem, p. 144.
} 
muito menos uma reafirmação acrítica desta. Pode-se dizer, portanto, que a ironia que relativiza as certezas deterministas de Bento perpassa inicialmente a vida e a morte de Brás Cubas em Memórias póstumas. Neste último, o choque entre as forças opostas são reveladas por intermédio do tom satírico do romance, que desmascara a desfaçatez classista e ressalta o esforço feito para moldar os ideais liberais em contexto conservador.

O liberalismo não aparece no cenário histórico-social como conexão da preservação do passado. Ao contrário, ele constituía uma das forças que trabalhavam por seu sepultamento, já que a manutenção do status quo ante colidia com seu sistema de valores e com sua filosofia política. Onde o Estado nacional emergente se converte em fator da preservação da escravidão, do império da dominação senhorial e da transformação da Monarquia constitucional em cômoda transação das elites senhoriais, isso se dá acima, independentemente e contra as "ideias" e os "princípios" liberais (FERNANDES, 1975, p. 46).

A correlação entre o "velho" e o "novo", segundo Florestan Fernandes (1975), evidencia que o Estado preenchia funções sociais manifestas em dois níveis distintos. As elites dos estamentos senhoriais precisavam dele tanto para manter as estruturas sociais que poderiam privilegiar seu prestígio social e, portanto, conduzi-las ao monopólio social do poder político quanto para expandir ou fomentar o aparecimento de condições econômicas, sociais e culturais que deveriam formar o substrato de uma sociedade nacional. A primeira consequência, chocante, tendo em vista a emergência de uma Nação, se torna mais evidente que a segunda.

As conclusões às quais o autor chega tornam-se pertinentes e cabíveis: as motivações ideológicas do liberalismo eram primariamente econômicas e apenas implicitamente políticas. Por outro lado, as motivações utópicas do liberalismo eram diretamente políticas e só posteriormente econômicas. Se o reverso "idealista" e "modernizador" não se fez sentir com maior ímpeto, tenacidade e universalidade, isso não se deve à sua ausência, mas à prevalência de condições sociais externas e subjetivas que o anularam, aqui e ali, ou o enfraqueceram ao longo do tempo.

O início da relação com Marcela no ano da independência política brasileira ganha destaque como fato prioritário. "Vamos de um salto a 1822, data da nossa independência política, e do meu primeiro cativeiro" ${ }^{3}$. Mais uma vez, o fato singular da vida do narrador pode ser deslocado para se compreender a etapa histórica decisiva para o país, se contrastado com os acontecimentos posteriores. A figura inicial de Marcela é idealizada pelo adolescente Cubas que acabara de entrar na puberdade e caracterizada com base nessa acepção pelo defunto:

\footnotetext{
${ }^{3}$ Ibidem, p. 72.
} 
(...) facilmente se imagina que mais de uma dama inclinou diante de mim a fronte pensativa, ou levantou para mim os olhos cobiçosos. De todas, porém, a que me cativou logo foi uma... uma... não sei se diga; este livro é casto, ao menos na intenção; na intenção é castíssimo. Mas vá lá; ou se há de dizer tudo ou nada. A que me cativou foi uma dama espanhola. Marcela, a 'linda Marcela', como lhe chamavam os rapazes do tempo. E tinham razão os rapazes. Era filha de um hortelão da Astúrias; disse-mo ela mesma, num dia de sinceridade, porque a opinião aceita é que nascera de um letrado de Madri, vítima da invasão francesa, ferido, encarcerado, espingardeado, quando ela tinha apenas doze anos. (...) Era boa moça, lépida, sem escrúpulos, um pouco tolhida pela austeridade do tempo, que lhe não permitia arrastar pelas ruas os seus estouvamentos e berlindas; luxuosa, impaciente, amiga de dinheiro e de rapazes (ASSIS, 2008, p. 73).

Três dias depois, o menino Brás Cuba é levado pelo tio para a ceia de moças, casa de Marcela, onde a beija a pretexto do esquecimento de um lenço. Os acontecimentos se desenrolam e a discrepância entre os interesses dos dois são ressaltados pelo narrador defunto, o que gera o posterior afastamento desses. Indo jantar na casa do Dutra, já adulto, Cubas deixa cair o vidro do relógio. Entra na primeira loja que vê, "era um cubículo - pouco mais empoeirado e escuro", e encontra Marcela envelhecida e "bexiguenta", o que o fez não a conhecer logo de cara. Sua moléstia física e espiritual desvenda uma vida massacrada pelo trabalho comercial já embasado pelos moldes capitalistas.

\footnotetext{
Não era esta certamente a Marcela de 1822; mas a beleza de outro tempo valia uma terça parte dos meus sacrifícios? Era o que eu buscava saber, interrogando o rosto de Marcela. O rosto dizia-me que não; ao mesmo tempo os olhos me contavam que, já outrora, como hoje, ardia neles a flama da cobiça. Os meus é que não souberam ver-lha; eram olhos da primeira edição (ASSIS, 2008, p. 117).
}

Ao decorrer da narrativa, Marcela é encontrada no interior de uma relojoaria, em estado degradante. Aqui a narrativa expressa uma verdade contida na vida, assim como coloca Lukács (1978), a de que "o típico não é, ele torna-se (...), um resultado da luta entre determinações sociais ricas de contradições” (p. 275). Assim, no percurso de Marcela implícito no resultado de sua vida - sua condição de classe comerciante vista por Brás Cubas ao necessitar do serviço de um relojoeiro -, são convergidos os traços que fazem das figuras singulares seres plenamente característicos, típicos, vivendo situações em que se exprime a sua essência típica; cada traço típico contendo em superadas em si determinações socialmente universais.

Por conseguinte, a situação final de Marcela nas Memórias configura-se artisticamente como momento típico em que vivia a classe proletária imediatamente após a independência política do país. Em situação de imigrante espanhola, Marcela tinha como uma das poucas possibilidades de sobrevivência, além do uso da beleza para adquirir o sustento próprio quando jovem, iniciar-se no ramo comercial para buscar o que se consolidava junto com o espírito do liberalismo - a partir do advento do sistema capitalista - como principal objetivo: a ascensão econômica. Fato é que Marcela, inserida na perspectiva de divisão capitalista do 
trabalho, degrada-se fisicamente e materializa-se não só como ser singular, mas como forma estética da condição cruel a que o trabalhador era e é submetido. Isso é o que se esconde por trás do relato do narrador, que, como senhor e detentor do poder econômico, e agora político, ignora totalmente, mas que se faz perceber e sentir concretamente a partir da construção artística que Machado propicia. Assim, segundo Lukács:

Recordemos que Marx, analisando a subordinação do homem à divisão capitalista do trabalho, sublinha precisamente o caráter estreito e animalesco desta subordinação. Este caráter se reproduz em todo homem que não se rebela, de um modo real e concreto, contra essas formas sociais. No campo ideológico, esta estreiteza encontra expressão no contraste em moda nas concepções do mundo destas últimas décadas: o contraste entre racionalismo e irracionalismo. A incapacidade do pensamento burguês de superar este contraste deriva, precisamente, de que ele tem raízes muito profundas na vida do homem submetido à divisão capitalista do trabalho (LUKÁCS, 2010B, p. 67).

A independência tornava-se um movimento de consolidação do poder geral nas mãos de poucos, e o estamento senhorial, como classe detentora das instituições sociais, econômicas, políticas e ideológicas, consequentemente fazia circular e difundir pela sociedade apenas seus desejos, projetos, pensamentos, que se colocavam por si só como veleidades pueris, ignorando ou não podendo perceber o emaranhado jogo contraditório se que fazia presente na essência da relação entre condição periférica brasileira e perspectiva liberal burguesa europeia.

Memórias póstumas de Brás Cubas, como reflexo verdadeiro da realidade, portanto, revela a verdade que envolvia o momento histórico-social brasileiro do século XIX: as tensões não se manifestaram de imediato, já que os agentes socialmente ativos fundiam momentos históricos contrastantes em sua visão do mundo, em sua consciência histórica e em sua atuação social construtiva. O surgimento de novos tipos humanos faz-se presente muito antes da extinção da escravidão e da universalização do trabalho livre, e a esfera de serviços sofrera extensa modificação, tanto ao nível das elites, quanto ao nível das massas ou dos assalariados. "O burguês já surge no Brasil como uma entidade especializada, seja na figura do agente artesanal inserido na rede de mercantilização, da produção interna, seja como negociante" (FERNANDES, 1975, p. 18).

A manutenção do sistema escravagista une-se de forma contraditória ao interesse dos mais poderosos à medida que a burguesia buscava a expansão do comércio. Crescimento comercial ligava-se, assim, à emergência, à propagação e à intensificação de movimentos inconformistas, em que o antiescravismo disfarçava e exprimia o afã de expandir a ordem social competitiva.

Com isso, percebe-se que, em situação periférica brasileira, as forças ideológicas vindas do outro lado do ocidente entram em choque com concretudes estruturais históricas 
divergentes de seus moldes originais. Assim, torna-se inviável a sua simples transposição de uma realidade a outra, visão admitida e propagada pela perspectiva decadentista burguesa e questionada satiricamente dentro das Memórias. A questão da revolução, entretanto, não se anula, apenas é reelaborada e entendida de modo diverso de seu sentido comum.

Graças e através da Independência, Nação e Estado nacional independente passaram a ser
"meios" para a burocratização da dominação patrimonialista e, o que é mais importante,
para a sua transformação concomitante em dominação estamental típica. Por conseguinte,
eles também eram "condições" e "meios: $1^{\circ}$ ) para resguardar as estruturas coloniais em que
se fundavam, econômica, social e moralmente, as formas tradicionais de dominação
patrimonialista; $2 .^{\circ}$ ) para privilegiar, politicamente, o prestígio social dos estamentos
senhoriais, fator essencial da burocratização da dominação patrimonialista e sua
transformação em dominação estamental propriamente dita. Portanto, sob esse aspecto, a
preservaça de velhas estruturas e o privilegiamento dos estamentos senhoriais possuíram,
na sociedade brasileira da época, um sentido revolucionário. Eram condições para a o
rompimento com o estatuto colonial e, ao mesmo tempo, para erigir-se a construção da
ordem social nacional a partir da herança colonial (ou seja, de uma "revolução dentro da
ordem") (FERNANDES, 1975, p. 55).

Como se pôde perceber até então, a revolução no Brasil ocorre de acordo com suas limitações enquanto condição de formação nacional atrasada e a partir de suas próprias contradições, o que gera consequências concretas e ideológicas específicas. Tendo em vista isso, a figuração estética de tal realidade não pode se fazer da mesma forma com que realizavam os grandes realistas franceses, por exemplo, na medida em que a matéria social e diversa. Como Edu Otsuka mostra, focando-se nos realistas alemães e na situação retardatária da Alemanha entre o final do século XVIII e a primeira metade do século XIX, o realismo não se restringe a "procedimento estéticos em si mesmos, e sim de uma articulação particular entre o modo de escrever e a matéria histórico-social” (OTSUKA, 2010, p. 37).

Machado de Assis, assim, figura artisticamente a realidade de modo diverso dos autores europeus por refletir um conteúdo social diferente e vê na sátira a forma mais correta de abarcar a totalidade da vida social a partir da junção contraditória entre aparência e essência. Viu-se como a figuração satírica é realizada no século XVIII por Voltaire em sua obra Cândido, ou o Otimismo, e, a partir dela, tentar-se-á mostrar como o momento histórico e o contexto de subdesenvolvimento influenciam Machado de Assis diretamente em sua composição satírica. 


\subsection{A figuração satírica machadiana: a estética da revolução em condição periférica}

Após se discutir, dentro das possibilidades, um pouco sobre a matéria social que envolvia o século XIX no Brasil e sua relação com o que acontecia na Europa, é possível pensar o caráter artístico formal da composição machadiana em Memórias póstumas de Brás Cubas. Na relação entre forma e conteúdo, em que este sempre é determinante daquela na composição artística da obra, a capacidade de suscitar experiências, a função evocadora da elaboração formal coloca-se como tarefa central da forma na estética segundo Lukács (1978). Vem-se tentando discutir e comprovar que Machado realiza, à sua maneira, um reflexo verdadeiro da realidade de seu tempo, aquele método artístico que possibilita

\footnotetext{
que artistas de valor elevem um homem médio à altura do típico, colocando-o em situações nas quais a contraditoriedade das suas determinações se manifesta não como "equilíbrio" médio, mas como luta dos contrários, e apenas a vacuidade desta luta, a queda no torpor, caracteriza definitivamente a figura como figura média (LUKÁCS, 1978, p. 274).
}

Brás Cubas, assim, é elevado à condição típica, mas não dá maneira exata como realizaram os grandes realistas europeus. Nas Memórias, a história está a mando de um narrador imerso nos valores artificiais burgueses, assim, a realidade pode e é destorcida como bem lhe convém. Todavia, é na aparente neutralidade do autor que repousa seu verdadeiro posicionamento, como todo escritor realista. Ao criar uma nova tipicidade, a do "defunto autor", permite que a elite conte sua própria história, aguçando toda a desfaçatez de classe, evidenciando "os nexos entre o aparente e o essencial, entre o que já morreu, mas insiste em permanecer fetichizadamente, não apenas da nossa realidade local, mas no andamento contraditório da sociedade dos homens" (CORRÊA, 2015, p. 46).

Partindo da concepção de que a forma artística empresta completa concreticidade a um dado tipo e produz uma unidade evidente dos traços que fazem das figuras singulares seres típicos vivendo momentos nos quais se exprime a sua essência típica, entende-se que as Memórias expressam o traço típico da sociedade oitocentista brasileira. A obra contém superadas em si, portanto, determinações socialmente universais.

Para pensar a composição satírica que possibilita concretizar tais afirmações, será analisada a formação educacional de base familiar tida por Brás Cubas a partir de sua própria explicitação. A história é distorcida principalmente pelo narrador e pelo pai deste a favor da criação de um status ilegítimo, artifício utilizado pela elite oitocentista brasileira para adequar-se ao padrão europeu que surgia, causando uma incompatibilidade ideológica e concreta entre aparência superficial e verdadeira essência. Faz-se, assim, com que a ironia acompanhe de perto a narração do protagonista e vise ao desmascaramento de uma vida de 
aparências mediante uma tradição educacional que reflete o patriarcalismo, em um primeiro plano, e a busca de interesses individuais de uma classe em um segundo, unindo, na obra literária, a mediocridade das relações sociais das personagens em ambiente familiar à sua verdadeira essência: um processo histórico universal, difuso e de difícil assimilação até hoje.

A tentativa de se forjar uma genealogia e a "deseducação" recebida pela personagem Brás Cubas são momentos iniciais da vida da protagonista que podem fornecer para nós um processo de compreensão importante acerca de uma fase decisiva para o futuro do nosso país que foi o século XIX.

A riqueza interior de um personagem literário deriva da riqueza de suas relações internas e externas, da dialética entre a superfície da vida as forças objetivas e psíquicas que atuam em profundidade. Quanto mais autêntico (isto é, quanto mais de acordo com a realidade) for no escritor este critério de medida, tão mais profundamente ele poderá ir até o fundo, tão mais ricas serão as determinações e tão mais móvel a vida que ele então saberá despertar e trazer à luz. E isto por uma razão: quanto mais autêntico for este critério de medida, tanto mais revelará as grandes contradições internas do desenvolvimento social, e tanto mais organicamente logrará o escritor aos grandes conflitos sociais o destino singular do personagem pelo qual se interessa (LUKÁCS, 2010B, p. 102).

Brás Cubas, ao assumir a posição central do discurso, deixa escapar todo o capricho que guiou sua vida, ações e todos aqueles que o cercavam. As rédeas livres dadas à personagem concretiza-se como forma mais cabível de crítica para a situação periférica do Brasil, por possuir um espaço estritamente domado pela classe dirigente sem riscos iminentes de confronto interno contra as classes marginalizadas. As contradições são intensificadas no ambiente literário, saltando aos olhos do leitor de forma farsesca e artificializada por meio de uma volubilidade que se evidencia complexa em sua composição.

Como característica frequente do início ao final das Memórias, a interrupção de Brás Cubas no capítulo sobre o Emplasto inicia a história de sua Genealogia no capítulo subsequente. O defunto-autor explicita aos poucos, desde o início, os critérios que guiarão a reserva de espaço, para cada parente, em sua autobiografia: Damião Cubas, tanoeiro natural do Rio de Janeiro, "onde teria morrido na penúria e na obscuridade, se somente exercesse a tanoaria" ${ }^{4}$, só é lembrado como fundador da família em meados do século XVIII porque "fezse lavrador, plantou, colheu, permutou o seu produto por boas e honradas patacas, até que morreu, deixando grosso cabedal a um filho, o licenciado Luís Cubas." ${ }^{5}$. Em suma, pode-se já começar a pensar em uma construção genealógica pautada pelo dinheiro e, em segundo plano, no plano confessável apenas após a morte, como disse Schwarz (1987), pelo desejo de cartaz, mecanismo que se funde à narrativa e navega por todo o romance.

\footnotetext{
${ }^{4}$ ASSIS, 2008, p. 44-45.

5 Ibidem, p. 45.
} 
As histórias e os fatos vividos passam por uma seleção minuciosa, e o protagonista das Memórias evidencia uma preocupação na contagem dos fatos, mergulhando fundo no mar de artifícios para compor um discurso da forma mais pomposa e artificiosa possível. Na escala da genealogia proposta, Luís Cubas aparece como verdadeiro ponto de partida para a família. Posto em nível de comparação com o pai tanoeiro, cuja qualidade de trabalho é colocada à prova - talvez pela qualidade do ofício -, Luís entraria para a face confessável, digna de ser lembrada pelos Cubas, ao passo que tenha ido a Coimbra estudar e foi o primeiro da família a exercer cargo público. Todavia, mais que as conquistas de objetivos gerais que estão no âmbito da cultura ocidental em conseguir o acesso a ensino educacional de qualidade (reconhecido) e estabilidade econômica dentro do funcionalismo público, a necessidade de ser alguém influente é argumento de peso na retórica da família Cubas. O fato de Luís Cubas ter conseguido ser um dos amigos particulares do vice-rei do Brasil, Antônio Álvares Cunha, é colocado por último na descrição do antepassado, o que pressupõe, em sua posição final na escala enumerativa, uma maior importância.

As confissões vão aumentando de grau progressivamente, até explicitar as consequências da ideologia familiar pautada na ideia fixa dos Cubas em engrandecerem-se, exemplificadas nas tentativas do bisneto de Damião (Bento Cubas, pai de Brás Cubas) de afastamento total a qualquer memória que retome o trabalho humilde da tanoaria exercido pelo bisavô. Um esforço é empregado, então, com o fim de manipular o passado. O pai do narrador, achando simplista demais as origens do sobrenome, recorre à falsificação destas mediante o entroncamento conveniente em uma família de um famoso fidalgo português, capitão-mor, que o inspirou a dar o nome ao filho. Com a objeção da família à façanha de Bento, este pula para a invenção de um novo princípio para o sobrenome: Cubas passaria a ser apelido de um cavaleiro digno, participante das jornadas na África, prêmio recebido por arrancar trezentas cubas dos mouros.

Com o plano aparentemente efetivado, a família oitocentista brasileira pôde, assim, gozar dos privilégios frívolos de uma genealogia forjada. Privilégios esses obtidos com o falseamento da história e que são desmascarados ao longo de toda a narrativa pelo método compositivo ao qual esta é submetida, à medida que vai tornando-se evidente a impossibilidade de modificação de um processo histórico particular sem que tal alteração afete a história como um todo. Vai ficando clara, assim, a maneira como a unicidade da ciência da história impossibilita a separação e o isolamento, acreditados pela concepção burguesa, dos ramos da ciência e seu desenvolvimento exclusivamente autônomo, concepção fortemente encontrada nos ideais da família Cubas. 
O que é proposto pelas manobras do pai e do filho Cubas é que o desenvolvimento da humanidade pode ser compreendido principalmente, ou exclusivamente, por intermédio de partes estanques do processo histórico e suas conexões imanentes, o que acaba abrindo brecha para as possibilidades de se considerar instrumentos de falsificação do passado, acreditandose não haver consequências profundas e que a fruição pode ser degustada a bel-prazer. Tanto o curso do enredo quanto a composição narrativa desmentem veementemente essa ideologia e põem à mostra as consequências mais cruéis dessa tomada de posição perante a vida, o que vai desde uma existência de faixada ilustrada pelo envolvimento mediado pelo dinheiro com uma cortesã espanhola, uma formação acadêmica medíocre em Coimbra e um envolvimento amoroso com Virgília em busca de mais autorrealização e continuidade da fama familiar, em que a traição torna-se ápice da vida, até a maior forma de desumanização percebida mediante o contato com o outro, como a desvalorização moral - sempre mediada pelo poder aquisitivo - da atitude do almocreve, a recompensa à Dona Plácida pela ajuda na traição de Brás Cubas e Virgília que substitui a complacência e os cuidados ao fim da vida da criada, e até mesmo a indiferença perante Eugênia e sua deficiência e a insensibilidade que despeja sobre a morte de Eulália.

Como já dito, o próprio curso narrativo se dispõe a negar a simples relação de causa e efeito que é proposta por Bento Cubas para a genealogia da família. A causa, uma falsificação e invenção de entroncamento a novos, importantes (e falsos) antepassados, não poderia simplesmente acarretar glória e fama para seus descendentes. A situação literária complexifica-se à medida que a obra, em sua segunda imediaticidade criada, vai evidenciando a profunda dialética presente na vida, que

\begin{abstract}
reconhece até mesmo nos dados mais elementares da realidade complexas interações de causas e efeitos. E o materialismo histórico acentua com particular vigor o fato de que, num processo tão multiforme e estratificado como o é a evolução da sociedade, o processo total do desenvolvimento histórico-social só se concretiza em qualquer dos seus momentos como uma intrincada trama de interações (LUKÁCS, 2010A, p.13).
\end{abstract}

Nesse segundo mundo proposto satiricamente pela arte, articula-se a aparência dos fenômenos profundamente ligados a sua essência verdadeira, mas afasta suas mediações dinâmicas, opondo-se de forma imediata. Assim, os artifícios utilizados pelo pai de Brás Cubas podem, e devem, ser interpretados e associados ao processo imbricado da elite brasileira no século XIX, que quis falsear o modo arcaico de dominação do país, que tinha como base econômica a escravidão, com ideais liberais advindos da realidade europeia, totalmente destoantes do contexto brasileiro ideologicamente atrasado. 
A aparência, como aparecer em si da própria Essência, se coloca, assim, como uma de suas determinações (LUKÁCS, 1978, p. 222) tanto na realidade como, consequentemente, na obra de arte. Entretanto, nesta última, a essência, ao encontrar-se completamente imersa no fenômeno, penetra-o de tal forma que se revela integralmente na manifestação deste, o que não ocorre na realidade concreta. As manifestações fenomênicas das Memórias carregam em si sua essência profunda, que se encontra intimamente ligada à vida social do homem à qual a verdadeira literatura sempre faz referência. Ao expor um "curto esboço genealógico" 6 , Brás Cubas torna público - ação que sempre pressupõe desfaçatez quando se trata da personagem as fraudes envolvidas na contagem do curso histórico familiar, o que vai desde as tentativas do pai, "varão, digno e leal como poucos" 7 , totalmente expostos e rebaixados pela ironia desoladora evidentemente explícita do romance, até o deslize implícito, e aparentemente sem importância, percebido por Marcelo Módolo ${ }^{8}$ na nota que desmente Brás Cubas em relação à afirmação da fundação da vila de São Vicente por seu homônimo, fidalgo português.

Da mesma forma que começa, o relato cessa: uma interrupção caprichosa com ares de necessidade para a sobreposição de memórias que parecem surgir quase que de imediato. Como característica marcante que adquire conceito de princípio formal para Schwarz (1987), a volubilidade narrativa da obra de abertura da fase machadiana madura surge como ponto importantíssimo para a discussão estabelecida.

Entre digressões da mais variada espécie, Brás Cubas chega ao dia de seu nascimento, 20 de Outubro de 1805. É interessante notar que é só a partir do capítulo X (Naquele dia) que se começa uma biografia cronologicamente linear - apesar de a volubilidade continuar sempre presente. Esta, aqui, encontra-se intimamente ligada às finalidades da vida burguesa, que dão delineamento aos participantes das Memórias, principalmente à protagonista, e guiam o enredo e o formato da narrativa. Por não possuírem continuidade de propósito, pois encontram o fastio como limite, os objetivos da elite brasileira da qual o narrador é membro dão o caráter volúvel destacado em circunstância nacional por estarem mediados pelo capricho. A feição barateada fica por conta do tom satírico, que rebaixa a ciência ao Emplasto Brás Cubas, a política ao tamanho da barretina, a filosofia ao Humanitismo e assim por diante, deixando a

\footnotetext{
${ }^{6}$ Ibidem, p. 44.

${ }^{7}$ Ibidem, p. 45.

${ }^{8}$ Responsável pela fixação do texto e pelas notas da edição utilizada das Memórias. A nota, número 12 , encontra-se, em sua íntegra, da seguinte maneira: "Na realidade, a primeira vila brasileira, atual cidade de São Vicente, foi fundada em 1532 por Martim Afonso de Sousa. Brás Cubas (1507-1592) foi um fidalgo e explorador português - fundador da vila de Santos, hoje cidade -, que governou por duas vezes a Capitania de São Vicente (1545-1549 e 1555-1556)".
} 
própria insuficiência de fôlego do dono da voz narrativa fazer o link entre os episódios, já que se encontram desprovidos de ação contínua.

Digamos então que no curso de sua afirmação a versatilidade do narrador faz pouco de todos os conteúdos e formas que aparecem nas Memórias, e os subordina, o que lhe proporciona uma espécie de fruição. Neste sentido a volubilidade é, como propusemos no início destas páginas, o princípio formal do livro (SCHWARZ, 2012, p. 31).

Como princípio formal, a volubilidade percorre toda a obra. Tratando-se do período da infância do narrador-autor como determinante para a formação de seu caráter, o capítulo de seu nascimento pode-nos contar muita coisa, a começar pela sempre autoafirmação que fica clara ao leitor desde as primeiras linhas. Até quando tenta disfarçar o ego inflado, escapa-lhe a presunção típica. "Naquele dia, a árvore dos Cubas brotou uma graciosa flor" 9 é a referência com a qual ele começa a narração do dia de seu nascimento. Com as atenções todas viradas para o recém-tornado "herói da casa", as profecias acerca do futuro do garoto são reflexos de uma força poderosíssima atuante no século XIX. As grandes possibilidades que revestem o caminho de Brás Cubas são traçadas antes mesmo de ele crescer, pois é destino selado a perpetuação da fama e do prestígio - por mais que forjados - que o nome da família carrega. Se por um lado, porém, estas rechaçam, por si só, qualquer espaço de discussão sobre a iniquidade social - apesar de ela ser realçada descaradamente dentro da sátira -, por outro, elas se chocam com força extrema contra o verdadeiro futuro da personagem, resultado da tentativa de manipulação do passado e das extravagâncias de classe.

Cada ente da família projeta sobre o menino uma previsão grandiosa: o tio João, antigo oficial de infantaria, imagina-o com "um certo olhar de Bonaparte"; já o tio Idelfonso, padre, acredita que o sobrinho seria um grande cônego, quem sabe até bispo. O que não faltam são apostas sobre o destino do mais novo herdeiro da família, com fichas sempre altas e nutridas esperanças. O pai, como figura central na "deseducação" de Brás Cubas, age com mais fôlego e demonstra suas expectativas com atitudes excêntricas, levantando-o aos céus, "como se intentasse mostrar-me à cidade e ao mundo" 10 .

Apesar de contar por alto os acontecimentos, como ele mesmo diz, pois teria ouvido de alguém anos depois - provavelmente do pai -, Brás Cubas parece ater-se aos detalhes mais frívolos “daquele famoso dia". Ignora a maior parte do que aconteceu, mas, se não conta "os mimos, os beijos, as admirações, as bênçãos, é porque, se os contasse, não acabaria mais o capítulo, e é preciso acabá-lo" ${ }^{11}$. Se por um lado não pode dizer nada sobre o batizado, por que nada lhe referiram a tal respeito, por outro, mostra-nos o tanto que sabe sobre o assunto.

\footnotetext{
${ }^{9}$ ASSIS, 2008, p. 60.

${ }^{10}$ Ibidem, p. 60.

${ }^{11}$ Ibidem, p. 61.
} 
Igreja de São Domingos, a festa mais elegante do ano de 1806, descendência nobre dos convidados, e até detalhes sobre o clima e o dia da semana entram para o vazio de recordações alegado pelo defunto-autor. A volubilidade aparece em uma de suas facetas mais peculiares na contradição de se contar nos mínimos detalhes o que acabara de se afirmar que não se recordava, confirmando assim que

o narrador não permanece igual a si mesmo por mais de um curto parágrafo, ou melhor,
muda de assunto, opinião ou estilo quase que a cada frase. Como ritmo variável, a
mobilidade vai da primeira à última linha do romance (SCHWARZ, 2012, p. 30).

Uma personalidade volúvel já concretizada e transfigurada para outro plano conta os detalhes que julga mais relevante acerca de sua experiência mundana e a sua maneira. $\mathrm{O}$ modo peculiar como é estabelecida a narração acaba nos dizendo mais do que a matéria narrada. Os detalhes escolhidos, a ordem planejada, a supressão e os jogos armados deixam evidente a não confiabilidade da protagonista.

Dessa forma, o que fica do primeiro contato com a parte mais alta da sociedade brasileira são novamente os valores vis, passados com ares de necessidade e que acabam moldando a formação da descendência oligárquica carioca refletida na figura de Brás Cubas. Os nomes dos padrinhos, como primeiras coisas aprendidas, exemplificam a ação de fora para dentro que era exercida sobre o garoto, o qual os recitava com muita graça, quer fazer-nos acreditar o contador da história. O intensificador aqui, mais do que o adjetivo, tenta passar certo ar naturalista para a futura personalidade do narrador, as correntes filosóficas em voga, como o Darwinismo Social, são diluídas no enredo e passam quase que despercebidas pelo olhar desatento. Os elogios dos vizinhos e desconhecidos dão indícios de uma realidade que o acolhe, reforçando a estrutura patriarcal ao satisfazer o desvario do pai que vê no filho a continuação de um projeto fajuto de propagação de valores medíocres. Saber andar antes do tempo é causa natural apresentada como justificativa velada para a superioridade usufruída perante a iniquidade social que permeia não só sua infância, mas sua vida inteira.

Conclui-se, logo, que a visão apresentada pelo narrador não corresponde à realidade efetiva, pois aquela se encontra calcada em princípios naturalistas, que determinam o meio como agente primordial da formação de um indivíduo. Em ambiente artístico, o Naturalismo encontra a descrição como método compositivo mais adequado, refletindo a vida como fragmentos lineares, entediantes e repetitivos, o que de certa forma pode ser compreendido pela forma como Brás Cubas conta sua vida - e pelo que ela é de fato - se não existisse sua extrema volubilidade e desfaçatez a mando de um objetivo maior da força satírica de Machado de Assis. 
A fragmentação do relato em episódios curtos e suas constantes digressões acabam refletindo a tentativa de narração de momentos isolados da vida da protagonista. As formas estéticas, constituídas e determinadas pela matéria social, da qual se tornam indissociáveis, aparecem nas Memórias como alavanca para a crítica proposta. O próprio fazer artístico de Brás Cubas propõe uma ligação com o método descritivo que tomou proporção de essencialidade com o desenvolvimento do processo capitalista no século XIX. Como afirma Lukács,

o triunfo tirânico da prosa do capitalismo sobre a poesia imanente da experiência humana, a crueldade da vida social, o rebaixamento do nível de humanidade são fatos objetivos que acompanham o desenvolvimento do capitalismo - e é deste desenvolvimento que decorre necessariamente o método descritivo. Contudo, uma vez que este método se constitui e é aplicado por escritores notáveis (...), ele repercute, numa ação de retorno, no reflexo literário da realidade. O nível poético da vida social decai, mas a literatura sublinha e aumenta esta decadência (LUKÁCS, 2010B, p. 165).

Como componente deste processo que é global, o Brasil também carrega, de acordo com suas especificidades, a decadência da prosa do capitalismo. Machado, para além de sua subjetividade individual, reúne, em figuras sensíveis, aquele particular que engloba e supera tanto o universal quanto o singular, visando uma representação mais adequada da situação periférica do país em relação à Europa.

O autor, nessa decisão de representar artisticamente a vida, assume uma tomada de posição independentemente do grau de consciência que tenha sobre esse processo. Tal partidarismo surge da obra no triunfo ou no fracasso de determinados propósitos, na vitória ou no insucesso e na carga estética que é empregada sobre as ações humanas e suas consequências. Machado, assim, ao lidar com a configuração de destinos humanos, assume, também, uma posição em face deles extremamente consciente. Não é a perspectiva sobre a vida da voz narrativa que prevalece, e sim o seu rebaixamento pela força satírica que a envolve, rebaixamento que em si contém uma tomada de posição que avalia e contrasta combativamente contra a visão de Brás Cubas.

Chega-se à infância da protagonista logo no capítulo subsequente e, apesar de o autor fazer referência ao poeta romântico William Wordsworth dando ao nome do capítulo um dos versos de seu poema no qual a infância é retratada com ingenuidade ${ }^{12}$, perceber-se-á que esse sentimento foi escasso nesse período de vida da personagem. Levando em consideração os

\footnotetext{
${ }^{12} \mathrm{O}$ poema referido se chama "Eu sinto o coração bater mais forte", de William Wordsworth, cujo verso "O menino é pai do homem", dá nome ao capítulo retratado das Memórias. Nessa curta estrofe de que é composto o poema o eu-lírico transparece possuir um sentimento que permanece desde a infância e é capaz de perdurar até a velhice. A tentativa dos românticos de eternizar a inocência da criança é claramente transportada ao romance brasileiro como forma irônica de crítica.
} 
três capítulos que se seguem nas Memórias $^{13}$, nos quais a infância de Brás Cubas é sintetizada por ele mesmo, é no primeiro deles em que se percebe mais nitidamente os tipos sociais brasileiros traçados por Machado no período oitocentista. O país é pensado a partir da educação que recebe uma criança nascida na corte carioca, e a extravagância de classe é permeada por um sentimento universal com um dos pontos de contato encontrados nas revoluções desencadeadas desde a Revolução Francesa: o historicamente necessário e novo.

No crescimento natural de Cubas, está escondida toda a desfaçatez e iniquidade social que a própria narração vai desmascarando aos poucos em seus desdobramentos irônicos. Em contraste com a comparação que faz de si mesmo com os gatos e as magnólias, encontra-se o "menino diabo" desde os cinco anos que quebrava o pescoço da escrava apenas por ter sido negada a ele a colher com doce de coco. Entre as diversas traquinagens de menino, que colocam, na voz do próprio narrador, em pé de igualdade, brincadeiras infantis, como esconder os chapéus das visitas e dar beliscões nas mulheres casadas, e a convivência nua e crua entre nobres e escravos na subordinação de Prudêncio e seu rebaixamento a cavalo de Brás Cubas, uma concepção de mundo molda-se baseada na mediocridade familiar, na inatividade materna, mas principalmente no incentivo por parte do pai.

Apesar de o narrador-autor ter consciência de seu "gênio indócil", o ambiente ao seu redor - estritamente familiar - o faz crer na robustez de seu espírito, e a justificativa mantém clara essa afirmação: "porque meu pai tinha-me em grade admiração; e se às vezes me repreendia, à vista de gente, fazia-o por simples formalidade: em particular dava-me beijos"14. As confissões se colocam porque se está do outro lado da vida, e não há nada mais a perder. Em seu discurso de autoculpabilidade ${ }^{15}$, o objetivo intranarrativo é esvaziado de reflexão moral e preocupação solidária. Pelo contrário, o ambiente do momento de vida da personagem representante de sua infância e suas implicações aparecem como justificativa do próprio autor - já morto - para sua personalidade vil e mesquinha, posicionando o foco sempre naquilo exterior a ele mesmo.

Os familiares de Cubas tornam-se alvo de uma perícia e análise minuciosa. A mãe, senhora fraca "de pouco cérebro e muito coração", vira o estereótipo da mulher submissa ao marido, religiosa e pouco influente na educação do filho; o pai, por admirá-lo, acaba dandolhe uma educação que "se tinha alguma coisa de boa, era no geral viciosa, incompleta e, em partes, negativa"; o tio João, com suas anedotas obscenas, não lhe respeitava a adolescência; o

\footnotetext{
${ }^{13}$ Capítulos XI (“O menino é pai do homem”), XII (Um episódio de 1814) e XII (Um salto).

${ }^{14}$ ASSIS, 2008 p. 63.

${ }^{15}$ Brás Cubas revela que admirou a desigualdade social e até tentou explicá-la.
} 
tio cônego Idelfonso era colocado como homem medíocre que não encarnava o espírito substancial da Igreja e estimava mais as exterioridades e vantagens do cargo que a questão sagrada e superior.

Ficam claras pela argumentação as influências familiares sofridas pelo menino Brás Cubas, tanto como a relação entre educação frouxa e volubilidade de caráter (SCHWARZ, 2012). Todavia, acreditar que esses seriam os únicos motivos da formação de sua personalidade é cair na ideologia naturalista determinista a qual faz parte da concepção do próprio autor da biografia ${ }^{16}$. A única possibilidade de domínio e contenção sobre o garoto aparece na figura da tia materna, dona Emerenciana, mas que se dissipa rapidamente pela pouca convivência que Cubas teve com a parenta. A conclusão à qual o narrador chega concretiza sua posição como integrante da família. Mesmo tendo certa consciência da expressão do meio doméstico detalhada por ele, da "vulgaridade de caracteres, amor das aparências rutilantes, do arruído, frouxidão da vontade, domínio do capricho, e o mais", a ironia concretiza-se no deslocamento que faz de si mesmo em relação aos outros: "Dessa terra e desse estrume é que nasceu esta flor" ${ }^{\prime 17}$. A suposta assimetria entre a flor (Brás Cubas) e o estrume (o ambiente familiar) serve de desconversa para a real desigualdade. Ademais, como assinala Schwarz (2012), a explicação adquire sentido inverso, e o que era para permanecer irrelevante segundo uma ideologia de classe, salta como grotesco a partir de uma visualização que reconhece os ideais progressistas que surgem naquela época e que começa a colocar na balança questões éticas discrepantes, com uma problematização machadiana que consegue abarcar e colocar em xeque ambas as visões contrastantes.

Assim, como afirma Enylton de Sá Rego (1989) em sua tese de doutorado, Machado cria com Brás Cubas um herói épico possível em nosso tempo, "um anti-herói que ironicamente anatomiza sua humanidade" (REGO, 1989, p. 177). De fato, há uma reescrita cômica do épico em Memórias póstumas, sem sua autoridade usual. Para o autor, o fato de a obra ser escrita em épico/cômico ligá-la-ia à tradição luciânica por retomar, dentre outros exemplos, Fielding, autor que acreditava no uso do ridículo como combate à hipocrisia e à vaidade disfarçadas sobre a autoridade do épico e que utilizava elementos literários condizentes com características da tradição luciânica. É possível perceber no romance machadiano características que o ligam a essa tradição, como a menção pelo autor da

\footnotetext{
${ }^{16}$ Como afirma Schwarz (2012): "O capítulo inspira-se no Naturalismo, embora para rivalizar com ele e superálo. Aí estão as pesquisas das causas, a observação metódica, o ânimo científico, e mesmo a tese de hereditariedade: as disposições melancólicas da mãe e as fátuas do pai transmitem-se ao fillho" (p. 130); e ainda em outro trecho: "O conjunto forma um ambiente social, dotado de força causadora, a ser contrastado com a causação quase física, e por isso mesmo 'científica', proposta pelo Naturalismo" (p. 131).

${ }^{17}$ ASSIS, 2008 p. 65.
} 
linhagem de sua descendência que vem dos satiristas clássicos, como no momento em que Brás Cubas cita Sêneca e Quincas Borba cita Erasmo de Roterdã, a criação de uma panaceia, como é o caso do Emplasto Brás Cubas, a apropriação do texto por meio da paródia, o ponto de vista do kataskopos (distanciado) e o caráter spoudogeloion (sério-cômico). No entanto, as especificidades nacionais e o confronto entre o velho e o novo captado pelo escritor brasileiro compõem a originalidade artística de Machado, que foi capaz de compor uma figuração correta do conteúdo específico que aparecia como essencialmente novo.

A afirmativa de Enylton de Sá Rego de que "o herói moderno tem que ter algo de "maravilhoso" (Ibidem, p. 167) relaciona-se intimamente com a escolha formal de Machado por intermédio da sátira, o que mostra de forma clara a capacidade subjetiva do autor na criação da individualidade da obra no que tange a compreensão efetiva dos fenômenos sensíveis e sua essência verdadeira para a figuração artística correta. Como afirma Lukács (2011), a sátira pode virar-se para o grotesco e para o fantástico, ligando a essência e o fenômeno de forma diferente daquela que ocorre na realidade, afastando-se as mediações reais. Aqui, a essência e o fenômeno são coincididos mediante o contraste entre os detalhes não típicos e a verdade do conteúdo: "O típico é assim alcançado por meio da abolição da forma contraditória no seio do conteúdo adequado de sua própria contradição" (LUKÁCS, 2011, p. 177). Ou seja, a obra literária assumida como satírica, a partir do momento em que é sentida a necessidade da utilização do elemento fantástico ${ }^{18}$ em sua composição, relaciona os fenômenos sensíveis de sua segunda imediaticidade e que estão fora da lógica que permeia a realidade social concreta (e, por isso, fantásticos) ao conteúdo verdadeiro presente na própria realidade.

Em Memórias póstumas de Brás Cubas, então, o romance atinge a verossimilhança plena ao figurar a atividade intelectual de um defunto, artifício fantástico por si mesmo, para compor um espaço artístico em que as forças motrizes do processo histórico-social se fundem à aparência imediata das coisas: em um integrante da classe dirigente brasileira, assim, a maleabilidade e a vulgaridade das ambições da elite se revelam em sua íntima contradição apenas após a morte e só poderiam sair, unicamente, por sua própria boca. A forma com que as Memórias se compõem configura-se como sátira efetiva já que

\footnotetext{
a sátira é um modo de expressão literária abertamente combativo. O que é figurado na sátira não é o porquê nem o contra o quê se combate, nem o próprio combate: é a própria forma da figuração que, em seu princípio e de modo imediato, assume a característica de um combate aberto (LUKÁCS, 2011, p. 168).
}

\footnotetext{
${ }^{18}$ Tal necessidade relaciona-se intimamente com o contexto periférico de cada país. Ver mais em Lukács, realismo e experiência periférica (Anotações de leitura), de Edu Otsuka (2010).
} 
O realismo de Machado de Assis impacta porque nele evidenciam-se os limites da sociedade contemporânea de seu tempo de maneira mais brutal e nítida que as demais composições literárias. Em sua forma, a relação com o conteúdo de classe se expressa mais imediatamente do que na maioria dos problemas formais da literatura, característica intrínseca à sátira, e todo autor satírico, combate uma classe, aquela que tenta sempre prolongar seu domínio sobre outra.

A situação particular do país se relaciona, como já dito, de uma realidade iniciada do outro lado do oceano, na medida em que se aprofunda nas origens e razões desse combate de classes. A partir da propagação dos ideais libertários pela Europa, desencadeada pela Revolução Francesa no século XVIII, as revoluções burguesas que lutaram contra a decisão do Congresso de Viena de restaurar a antiga ordem monárquica europeia na primeira metade do século XIX, o que ficou conhecido como a Primavera dos Povos, tiveram impactos mundiais ecoando também em território latino-americano. No Brasil, por exemplo, houve a Revolução Praieira em Pernambuco em 1848, que buscava a contemplação de novas classes no direito ao voto, dentre outras medidas, foi facilmente exterminada. É especialmente neste ano em que ocorre a filiação da burguesia europeia à classe conservadora, quando aquela abandona os ideais revolucionários e liberais nos quais acreditava junto ao proletariado para defender interesses político-econômicos particulares.

Como a literatura é produto do trabalho intelectual de seres concretos, cabe a ela também refletir os processos históricos e as questões ideológicas que perpassam a vida dos homens, a fim de fornecer um quadro mais rico da realidade. Talvez sem um foco e uma preocupação em desmiuçar em categorias estéticas a dimensão psicológica do artista e de suas personagens, dimensão relevante e ressaltada por Rouanet (1991), as qualidades humanas existentes na particularidade pessoal são consideradas pela verdadeira crítica lukacsiana e abarcam, até certo ponto, a dimensão psicológica defendida por Sérgio Paulo Rouanet. Ocorreria, portanto, nesse processo de composição artística, a

elevação da personalidade criadora da singularidade individual particular à particularidade, à sua própria particularidade. Tudo o que na singularidade imediata do artista é importante para o seu trabalho criador pode se afirmar sem modificações, inclusive se acentuando com o aumento das tarefas. A transformação da particularidade individual em generalização estética, em particularidade, ocorre em seguida ao contato com a realidade objetiva, em seguida ao esforço de reproduzir fielmente esta realidade, de um modo profundo e verdadeiro. Precisamente a sensibilidade do espírito de observação, a fantasia espontânea, etc., permitem criar formas e fazem surgir situações cuja própria lógica interna supera os preconceitos da personalidade particular, entra em conflito com eles. O nível artístico depende, precisamente, em larga medida, do resultado destas colisões (LUKÁCS, 1978, p. 201-202). 
A subjetividade artística de Machado consegue achar aquele ponto exato de influência entre concepção de mundo e realização formal que compreende o "Triunfo do Realismo" (LUKÁCS, 1978), elevando sua personalidade criadora acima da singularidade individual, transpondo esta última, em um procedimento dialético-dinâmico, a uma própria particularidade, uma generalização estética formada a partir do contato com a realidade objetiva. As qualidades humanas contidas na particularidade pessoal, o que pode presumir o caráter psicológico do autor considerado e ressalvado por Sergio Paulo Rouanet (1991) como dimensão deixada de lado pela crítica que envolve Machado, são tidas como base de toda aptidão artística para Lukács.

Memórias póstumas é, assim, um romance colocado como aquele justo combate contra os vícios essenciais da ordem social brasileira em contexto mundial sobre a forma de uma sátira que figura efetivamente no fenômeno a essência da classe e da sociedade brasileiras, pois percebe e ressalta a doença do sistema, que o condena a uma falência iminente. Machado analisa as situações que combate em seus fundamentos objetivos e luta contra elas precisamente através de sua representação tais quais são, apropriando-se da indignação, do desprezo e do ódio "tornados clarividentes graças à paixão, à reflexão e à compreensão do real" (LUKÁCS, 2011, p. 181) por intermédio de seu partidarismo em frente aos conflitos que emergem da vida.

Este ódio sagrado ${ }^{19}$ vivido pela classe revolucionária, reprimida nacionalmente por questões particulares relacionadas ao sistema político-econômico brasileiro da época, é encarnado, de forma original, na obra machadiana, especialmente nas Memórias, nas quais se vê, inicialmente, a ascensão e ambientalização de um membro da elite brasileira oitocentista refletidas em sua infância, assim como em sua genealogia. Tais sentimentos íntimos da sátira são veículos eficazes para uma revolução real, que se inicia a partir do momento em que mentes avançadas e progressistas como a de Machado de Assis refletem o processo da necessidade de destruição de uma sociedade que não é mais viável e do surgimento de uma sociedade fundamentalmente nova. Tal ódio gerado contra a classe opressora exprime dialeticamente o verdadeiro amor de Machado de Assis pela humanidade:

Sem um tal amor pela vida e pelos homens, amor que implica necessariamente o mais profundo ódio pela sociedade, pelas classes e pelos homens que os humilham e ofendem, não pode surgir hoje no mundo capitalista um realismo verdadeiramente grandioso. Este amor, bem como o ódio que lhe é complementar, levam o escritor a descobrir a riqueza das relações da vida humana e a representar o mundo do capitalismo como uma incessante luta contra as forças que destroem e matam estas relações humanas (LUKÁCS, 2010B, p. 85).

\footnotetext{
19 "sagrado" é um termo utilizado por Lukács no texto "A questão da sátira”, de Arte e sociedade, 2011, talvez por representar uma forma específica de ódio que nasce nas classes progressistas e tem o intuito de, por intermédio da revolução, extinguir a sociedade de classes.
} 


\section{CONSIDERAÇÕES FINAIS}

A partir do exposto e desenvolvido nas páginas anteriores, consegue-se visualizar Memórias póstumas de Brás Cubas para além da vida particular de um ex-participante da classe dirigente do país: coloca-se como obra artística que evidencia e reflete de forma mais precisa as contradições que envolviam a formação do Brasil como Nação independente a partir da manutenção das estruturas sociais, econômicas e morais graças aos desejos particulares da classe que comandou o processo revolucionário: os estamentos senhoriais. A relação entre forma e conteúdo no âmbito da arte, assim, foi abordada visando à maior compreensão do uso da sátira como método mais propício para Machado conseguir figurar tal momento histórico dinâmico e complexo.

A classe dirigente brasileira, ao estar sempre evidenciada no primeiro plano dos processos sociais guiando o desenvolvimento da história, torna-se linha de frente e assume o comando da narrativa nas Memórias também. Entretanto, como desdobramento satírico, como jogo dialético específico entre aparência e essência, o reflexo artístico expõe ironicamente o caráter superficial dessa elite, que assume a decadência ideológica burguesa e a desenvolve a sua maneira, com desfaçatez e artificialidade.

Logo, viu-se como a sátira machadiana se diferencia da sátira europeia na medida em que se liga a um conteúdo específico. Ela realça as desigualdades sociais e os privilégios de classe em um contraste que era sempre colocado debaixo dos panos dentro de um contexto específico de revolução burguesa. Dessa forma, os valores vis e áridos de exaltação da fama e do poder são reduzidos a percepções mesquinhas e limitadas de mundo pela forma estética, que encarna em si o partidarismo do autor em frente aos processos históricos sociais da época.

Percebe-se, por conseguinte, que a composição literária de conteúdos concretos é efetivada pela honestidade do escritor e por sua capacidade de perceber no desenvolvimento da história humana as forças atuantes e suas relações dinâmicas. Memórias póstumas de Brás Cubas, assim, traz uma etapa do percurso da humanidade em direção ao progresso, etapa essa cheia de desvios de percurso, mas que pondera e defende a integridade humana no sentido do avanço material e espiritual do indivíduo. 


\section{REFERÊNCIAS BIBLIOGRÁFICAS}

ASSIS, Machado de. Memórias póstumas de Brás Cubas. São Paulo: Globo, 2008.

CANDIDO, Antonio. Esquema de Machado de Assis. In: Vários escritos. 4. ed. São Paulo, Rio de Janeiro: Duas Cidades, Ouro sobre Azul, 2004.

CORRÊA, Ana Laura dos Reis. As duas faces das medalhas: dialética aparência e essência em "Teoria do medalhão" e "O emplasto". O eixo e a roda, Belo Horizonte, v. 24, n. 2, p. 31 47, 2015.

FERNANDES, Florestan. A revolução burguesa no Brasil: ensaio de interpretação sociológica. 2. ed. Rio de Janeiro: Zahar Editores, 1975.

FONSECA, Daniel Gomes da. Em torno da ironia: análise de Dom Casmurro, de Machado de Assis. São Paulo, 2014. 325 p. Dissertação (Mestrado em Letras), Faculdade de Filosofia, Letras e Ciências Naturais de São Paulo, 2014.

LUKÁCS, György. “A questão da sátira”. In: Arte e sociedade: escritos estéticos 1932-1967.

2. ed. Rio de Janeiro: Editora UFRJ, 2011.

Introdução aos escritos estéticos de Marx e Engels. In: MARX, Karl \& ENGELS, Friedrich. Cultura, arte e literatura: textos escolhidos. São Paulo: Expressão Popular, 2010A. p. 11-38.

Introdução a uma estética marxista. Rio de Janeiro: Civilização Brasileira, 1978.

Marxismo e teoria da literatura. São Paulo: Expressão Popular, 2010B.

OTSUKA, Edu Teruki. Lukács, realismo e experiência periférica (Anotações de leitura). Literatura e Sociedade. Número 13. São Paulo, USP, 2010.

REGO, Enylton de Sá. O calundu e a panaceia: Machado de Assis, a sátira menipeia e a tradição luciânica. Rio de Janeiro: Forense Universitária, 1989.

SCHWARZ, Roberto. Complexo, moderno, nacional e negativo. In: Que horas são? São Paulo: Cia. das Letras, 1987, p. 115-128.

Um mestre na periferia do capitalismo: Machado de Assis. 2. ed. São Paulo: Duas Cidades, Ed. 34, 2012.

VOLTAIRE. Cândido, ou o Otimismo. 1. ed. São Paulo: Penguin Classics, Companhia das Letras, 2012. 